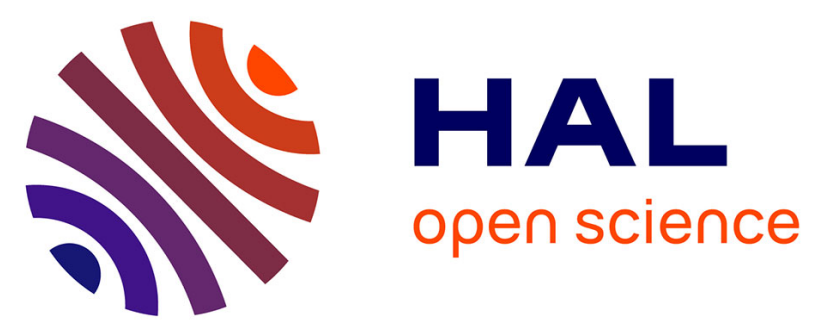

\title{
Additive-Free Formic Acid Dehydrogenation Catalyzed by a Cobalt Complex
}

Lentz Nicolas, Alicia Aloisi, Pierre Thuéry, Emmanuel Nicolas, Thibault Cantat

\section{- To cite this version:}

Lentz Nicolas, Alicia Aloisi, Pierre Thuéry, Emmanuel Nicolas, Thibault Cantat. Additive-Free Formic Acid Dehydrogenation Catalyzed by a Cobalt Complex. 2020. cea-02933763

\section{HAL Id: cea-02933763 https://hal-cea.archives-ouvertes.fr/cea-02933763}

Preprint submitted on 8 Sep 2020

HAL is a multi-disciplinary open access archive for the deposit and dissemination of scientific research documents, whether they are published or not. The documents may come from teaching and research institutions in France or abroad, or from public or private research centers.
L'archive ouverte pluridisciplinaire HAL, est destinée au dépôt et à la diffusion de documents scientifiques de niveau recherche, publiés ou non, émanant des établissements d'enseignement et de recherche français ou étrangers, des laboratoires publics ou privés.

\section{(ㅇ)(1) $\$$}

Distributed under a Creative Commons Attribution - NonCommercial - NoDerivatives| 4.0 


\section{Additive-Free Formic Acid Dehydrogenation Catalyzed by a Cobalt Complex}

Lentz Nicolas, Alicia Aloisi, Pierre Thuéry, Emmanuel Nicolas, Thibault Cantat

Submitted date: 01/09/2020 - Posted date: 02/09/2020

Licence: CC BY-NC-ND 4.0

Citation information: Nicolas, Lentz; Aloisi, Alicia; Thuéry, Pierre; Nicolas, Emmanuel; Cantat, Thibault (2020): Additive-Free Formic Acid Dehydrogenation Catalyzed by a Cobalt Complex. ChemRxiv. Preprint. https://doi.org/10.26434/chemrxiv.12901925.v1

The reversible storage of hydrogen through the intermediate formation of Formic Acid (FA) is a promising solution to its safe transport and distribution. However, the common necessity of using bases or additives in the catalytic dehydrogenation of FA is a limitation. In this context, two new cobalt complexes (1 and 2) were synthesized with a pincer $\mathrm{PP}(\mathrm{NH}) \mathrm{P}$ ligand containing a phosphoramine moiety. Their reaction with an excess FA yields a cobalt(I)-hydride complex (3). We report here the unprecedented catalytic activity of 3 in the dehydrogenation of FA, with a turnover frequency (TOF) of $4000 \mathrm{~h}^{-1}$ and a turnover number (TON) of 454, without the need for bases or additives. A mechanistic study reveals that the ligand has a non-innocent behaviour due to intermolecular hydrogen bonding, which is influenced by the concentration of formic acid

File list (4)

text.pdf $(572.08 \mathrm{KiB})$ view on ChemRxiv • download file

ESI.pdf (1.66 MiB) view on ChemRxiv • download file

DFT_Coordinates.xyz (64.67 KiB) view on ChemRxiv • download file 


\title{
Additive-Free Formic Acid Dehydrogenation Catalyzed by a Cobalt Complex ${ }^{\dagger}$.
}

\author{
Nicolas Lentz, Alicia Aloisi, Pierre Thuéry, Emmanuel Nicolas and Thibault Cantat* \\ Université Paris-Saclay, CEA, CNRS, NIMBE, 91191, Gif-sur-Yvette, France. E-mail: thibault.cantat@cea.fr \\ Supporting Information Placeholder
}

\begin{abstract}
The reversible storage of hydrogen through the intermediate formation of Formic Acid (FA) is a promising solution to its safe transport and distribution. However, the common necessity of using bases or additives in the catalytic dehydrogenation of FA is a limitation. In this context, two new cobalt complexes (1 and $\mathbf{2})$ were synthesized with a pincer PP(NH)P ligand containing a phosphoramine moiety. Their reaction with an excess FA yields a cobalt(I)-hydride complex (3). We report here the unprecedented catalytic activity of $\mathbf{3}$ in the dehydrogenation of FA, with a turnover frequency (TOF) of $4000 \mathrm{~h}^{-1}$ and a turnover number (TON) of 454 , without the need for bases or additives. A mechanistic study reveals that the ligand has a non-innocent behaviour due to intermolecular hydrogen bonding, which is influenced by the concentration of formic acid.
\end{abstract}

The share of renewable energies in the European energetic mix has never been higher, reaching $13.9 \%$ in $2017 .{ }^{1}$ However, with their increased penetration, the long-term storage of intermittent energies becomes more and more urgent, in order to accommodate for seasonal variations in production and consumption. ${ }^{2}$ Hydrogen is a promising energy carrier for that purpose, as it is readily available and has a high energy density; but its storage as a compressed gas is still problematic. ${ }^{3}$ Chemicals such as Formic Acid (FA) can act as Liquid Organic Hydrogen Carriers (LOHCs) through hydrogenation and dehydrogenation cycles. ${ }^{4-8}$

The catalytic dehydrogenation of FA has been extensively studied during the past decade. Several homogeneous complexes, based on noble metals such as iridium, ${ }^{9-11}$ rhodium, ${ }^{12-14}$ molybdenum, ${ }^{15}$ ruthenium $^{16-19}$ and osmium $^{20}$ have been reported as catalysts for this reaction. These studies demonstrated that the ligand architecture has a crucial impact on the catalyst activity and stability and therefore governs the catalysts turnover number (TON) and turnover frequency (TOF). In parallel, several groups developed catalysts based on the use of $3 \mathrm{~d}$ group metals as a promising alternative to expensive and potentially rare noble metals. Yet, this substitution often comes at the price of a decrease reactivity and stability. ${ }^{21}$ Beller et al. pioneered the use of iron complexes in 2010, and a number of PNP pincer ligands chelated to an iron centre have been reported since. ${ }^{22-31}$ Manganese complexes have also been reported to be active in this reaction, as reported by Boncella, Tondreau, et al. and Beller et al. ${ }^{32-34}$ The activity of other $3 \mathrm{~d}$ metals was assessed over the past few years, using nickel (Junge, Enthaler et al. and Parkin et al.), ${ }^{35,36}$ copper (Correa et al.), ${ }^{37}$ and cobalt (Beller et al. and Onishi et al.). ${ }^{38,39}$ Group 13 compounds were also investigated, namely aluminium by the group of Berben in $2014,{ }^{40}$ and boron by our group. ${ }^{41}$

The presence of participative ligands is a consistent feature in the majority of the reported examples, to include an internal base in the coordination sphere of the catalyst to activate FA. ${ }^{42-}$
${ }^{45}$ A second feature of interest, especially in the case of $3 \mathrm{~d}$ group metals, is that an external base or additives such as $\mathrm{BF}_{4}$ salts are often necessary to retain a catalytic activity. We recently reported a new ligand featuring an $\mathrm{N}-\mathrm{H}$ moiety on a triphosphane backbone that helped stabilizing copper hydride complexes. ${ }^{46}$ This chelating ligand presents a phosphoramine function $\left(\mathrm{R}_{2} \mathrm{P}_{-}\right.$ NHR') together with two phosphines, which can act as a pendant amine and a participative ligand. It is hence an excellent platform to design catalysts for the dehydrogenation of formic acid. Herein, we report the coordination properties of this new $\mathrm{PP}(\mathrm{NH}) \mathrm{P}$ ligand with cobalt, and describe the synthesis of two $\mathrm{PP}(\mathrm{NH}) \mathrm{P}-\mathrm{Co}(\mathrm{II})$ complexes, 1 and $\mathbf{2}$, and a $\mathrm{PP}(\mathrm{NH}) \mathrm{P}-\mathrm{Co}(\mathrm{I})-\mathrm{H}$ complex, 3 . The catalytic activity of all three complexes in the dehydrogenation of formic acid was investigated, and a theoretical mechanistic study unveiled the role of the ligand in the remarkable activity of $\mathbf{3}$.

The $\mathrm{PP}(\mathrm{NH}) \mathrm{P}$ ligand was prepared following the literature procedure, ${ }^{46}$ and its coordination was investigated with two different cobalt precursors (Scheme 1): cobalt(II) chloride or cobalt(II) acetate were readily coordinated by the $\mathrm{PP}(\mathrm{NH}) \mathrm{P}$ ligand in a THF solution at $80^{\circ} \mathrm{C}$, to yield complexes $\mathbf{1}$ and $\mathbf{2}$ respectively, which were isolated quantitatively as brown powders. Both complexes are paramagnetic, which prevented any conclusive NMR analysis, but single crystals of 1.THF were obtained from the evaporation of a saturated THF solution (Figure 1a). All efforts towards crystallization of $\mathbf{2}$ remained unfruitful. In the molecular structure of $\mathbf{1}$, the cobalt atom adopts a distorted square pyramidal geometry $(\tau=0.18)^{47}$ with a chlorine atom in the axial position and the phosphine and second chlorine ligands in the basal positions. An hydrogen bond was observed between one chlorine atom and the phosphoramide hydrogen, as expected for such a participative ligand. 


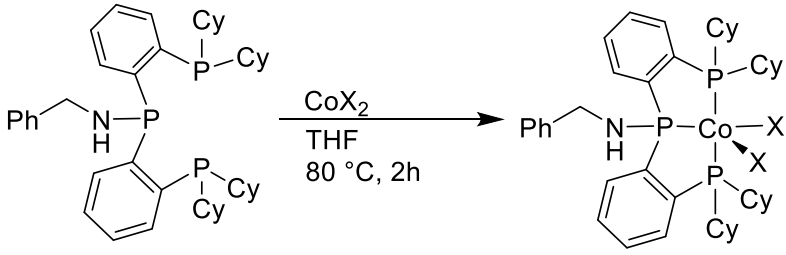

quantitative 1: $\mathrm{X}=\mathrm{Cl}$ 2: $X=O A C$

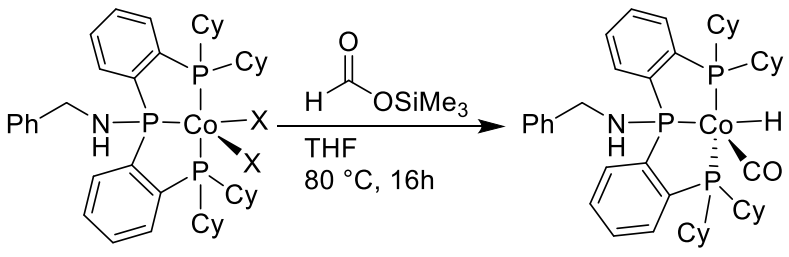

1: $\mathrm{X}=\mathrm{Cl}$

2: $X=O A C$

$3(86 \%)$

Scheme 1: Synthesis of Co(II)-complexes 1 and 2.

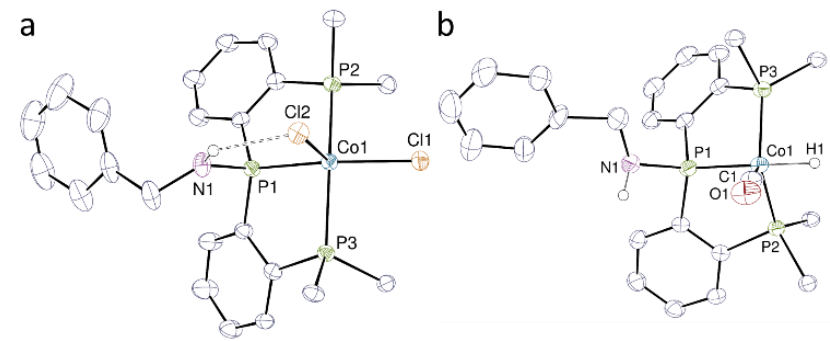

Figure 1: (a) Molecular structure of 1. Carbon-bound hydrogen atoms and cyclohexyl rings have been omitted. The hydrogen bond is shown as a dashed line. Selected bond distances $(\AA)$ and bond angles $\left({ }^{\circ}\right)$ : $\mathrm{P} 1-\mathrm{N} 1$ 1.660(4); $\mathrm{P} 1-\mathrm{Co} 1$ 2.1397(12); P2-Co1 2.2444(12); P3-Co1 2.2775(12); Cl1-Co1 2.2526(11); Cl2-Co1 2.4132(11); Cl1-Co1-Cl2 98.24(4); Cl1-Co1-P1 167.45(5); Cl1-Co1-P2 91.90(4); Cl1-Co1-P3 92.30(4); Cl2-Co1-P1 94.30(4); Cl2-Co1-P2 100.08(4); Cl2-Co1-P3 102.36(4); P2-Co1-P3 156.32(5); P1-Co1-P2 86.28(4); P1-Co1-P3 84.59(4). (b): Molecular structure of 3. Carbon-bound hydrogen atoms and cyclohexyl rings have been omitted. Selected bond distances $(\AA)$ and bond angles $\left({ }^{\circ}\right)$ : $\mathrm{P} 1-\mathrm{N} 1$ 1.705(2); P1-Co1 2.1224(7); P2-Co1 2.1528(7); P3-Co1 2.1540(7); H1-Co1 1.46(3); C1-Co1 1.731(3); C1-O1 1.163(3); C1-Co1-H1 91.4(11); C1-Co1-P1 104.71(8); $\mathrm{C} 1-\mathrm{Co} 1-\mathrm{P} 2 \quad$ 111.99(8); C1-Co1-P3 120.07(8); H1-Co1-P1 163.4(11); H1-Co1-P2 82.3(11); H1-Co1-P3 87.9(10); P2-Co1-P3 127.16(3); P1-Co1-P2 87.74(3); P1-Co1-P3 87.60(3).

The reactivity of both Co(II) complexes $\mathbf{1}$ and $\mathbf{2}$ was investigated with 5 equivalents of formic acid for $2 \mathrm{~h}$ at $150{ }^{\circ} \mathrm{C} .{ }^{1} \mathrm{H}$ NMR showed the total consumption of formic acid, together with the formation of a new diamagnetic complex, $\mathbf{3}$, featuring two singlets at 97.2 and $159.7 \mathrm{ppm}$ in ${ }^{31} \mathrm{P}\left\{{ }^{1} \mathrm{H}\right\}$ NMR and a characteristic doublet of triplet at $-10.91 \mathrm{ppm}$ in ${ }^{1} \mathrm{H}$ NMR., indicative of a cobalt(I) hydride complex. In addition, GC analysis of the head space showed the selective consumption of FA into $\mathrm{CO}_{2}$ and $\mathrm{H}_{2}$. Although 3 could not be isolated pure from stoichiometric reactions between $\mathbf{1}$ or $\mathbf{2}$ and $\mathbf{2}$ equiv. FA, it was successfully prepared by replacing FA with a surrogate which cannot undergo dehydrogenation reactions: trimethylsilylformate. Complexes 1 and 2 both reacted with 3 equiv. TMS$\mathrm{OCHO}$, to give, after $16 \mathrm{~h}$ at $80{ }^{\circ} \mathrm{C}, \mathrm{Co}^{\mathrm{I}}$ complex 3 as an orange solid in $86 \%$ yield (Scheme 1). Crystals of 3.2.5dioxane were obtained from a saturated 1,4-dioxane solution (Figure 1b) and confirmed the presence of the hydride, together with a carbonyl ligand. In the molecular structure of $\mathbf{3}$, the cobalt atom adopts a distorted trigonal bipyramidal geometry $(\tau=0.60)$ with the central phosphorus and the hydride in the axial positions $\left(\mathrm{H} 1-\mathrm{Co} 1-\mathrm{P} 1=163.4(11)^{\circ}\right)$ and the remaining phosphines and carbon monoxide in the equatorial positions, similar to previously reported hydrido carbonyl cobalt complexes. ${ }^{48-50}$ The $\mathrm{Co} 1-\mathrm{H} 1$ and $\mathrm{Co} 1-\mathrm{C} 1$ bonds are typical of such structures, with lengths of 1.46(3) and 1.731(3) A respectively and comparable to those found in $\left[\mathrm{Co}(\mathrm{CO}) \mathrm{H}\left(\mathrm{PPh}_{3}\right)_{3}\right] \quad(1.41(9)$ and $1.704(17) \AA)^{48}$

The catalytic activities of complexes $\mathbf{1}, \mathbf{2}$ and $\mathbf{3}$ were finally investigated in the dehydrogenation of FA at $80^{\circ} \mathrm{C}$ in 1,4 -dioxane, with 0.5 mol\% loading (Figure 2). While 1 was found inactive at $80{ }^{\circ} \mathrm{C}, 2$ reached a production of $79 \mathrm{~mL}$ of gas after 20 min, corresponding to a TON of 165 . On the other hand, 3 reached full conversion after only $10 \mathrm{~min}$ of reaction. Interestingly, an induction period was observed with $\mathbf{2}$ in the first minute of the catalysis, suggesting that 2 might be converted to the active species, supposedly $\mathbf{3}$, according to the reactivity noted hereabove. In fact, $\mathbf{3}$ was observed as the major species, after decomposition of FA with $\mathbf{2}$. Both $\mathbf{2}$ and $\mathbf{3}$ have unprecedented activities for homogeneous cobalt complexes with $\mathrm{TON}_{1 \mathrm{~h}}=165$ and 200, compared to the MACHO ligand-bound cobalt-based catalyst reported by Beller et al. in the absence of any additive (no activity reported) or base $\left(\mathrm{TON}_{1 \mathrm{~h}}=29\right.$ with 2 equiv. of $\mathrm{Na}-$ $\mathrm{BEt}_{3} \mathrm{H}$ with respect to the complex). ${ }^{39}$

Catalyst 3 reached a full conversion of FA within the first 10 min of the reaction with a TOF of $4000 \mathrm{~h}^{-1}$ (Table 1 , entry 1). The catalyst was not only active in dioxane, but also in toluene $\left(\mathrm{TON}_{1 \mathrm{~h}}=154, \mathrm{TOF}_{1 \min }=250 \mathrm{~h}^{-1}\right)$ or even in protic solvents, incl. water $\left(\mathrm{TON}_{1 \mathrm{~h}}=102, \mathrm{TOF}_{1 \min }=750 \mathrm{~h}^{-1}\right)$, although a diminished stability and activity were noted in both cases (Table 1, entries 1,2 and 3). The impact of the solvent on the activity and stability of $\mathbf{3}$ might result from its influence on the solubility of the complexes as well as heterolytic bond cleavage and stabilization of ionic intermediates. ${ }^{51,52}$ Finally, halving or doubling the FA concentration led to decreased kinetics with lower $\mathrm{TOF}_{1 \min }\left(1125\right.$ or $750 \mathrm{~h}^{-1}$ respectively, vs. $4000 \mathrm{~h}^{-1}$ at $\left.1 \mathrm{M}\right)(\mathrm{Ta}-$ ble 1, entries 1, 4 and 5), suggesting a complex rate order for FA.

Table 1. FA dehydrogenation catalysed by 3 .

\begin{tabular}{|c|c|c|c|c|c|}
\hline Entry & $\begin{array}{l}\text { Solvent } \\
\left(\text { Conc mol.L }{ }^{-1}\right)\end{array}$ & $\begin{array}{l}V_{1 \min } \\
(\mathbf{m L})\end{array}$ & $\begin{array}{l}\mathrm{V}_{1 \mathrm{~h}} \\
(\mathrm{~mL})\end{array}$ & $\mathrm{TON}_{1 \mathrm{~h}}$ & $\begin{array}{l}\text { TOF 1min } \\
\left(h^{-1}\right)\end{array}$ \\
\hline 1 & 1,4-dioxane (1) & 32 & 96 & 200 & 4000 \\
\hline 2 & Water (1) & 6 & 49 & 102 & 750 \\
\hline 3 & Toluene (1) & 2 & 74 & 154 & 250 \\
\hline 4 & 1,4-dioxane (2) & 6 & 49 & 106 & 750 \\
\hline 5 & 1,4-dioxane $(0.5)$ & 9 & 79 & 169 & 1125 \\
\hline
\end{tabular}

Conditions: FA $(2 \mathrm{mmol})$ in solvent and $3(0.5 \mathrm{~mol} \%)$ at $80{ }^{\circ} \mathrm{C}$. 


$$
\mathrm{HCOOH} \stackrel{\text { Cat }(0.5 \mathrm{~mol} \%)}{\stackrel{\text { 1,4-dioxane }}{80^{\circ} \mathrm{C}, \mathrm{t}(\min )}} \rightarrow \mathrm{H}_{2}+\mathrm{CO}_{2}
$$

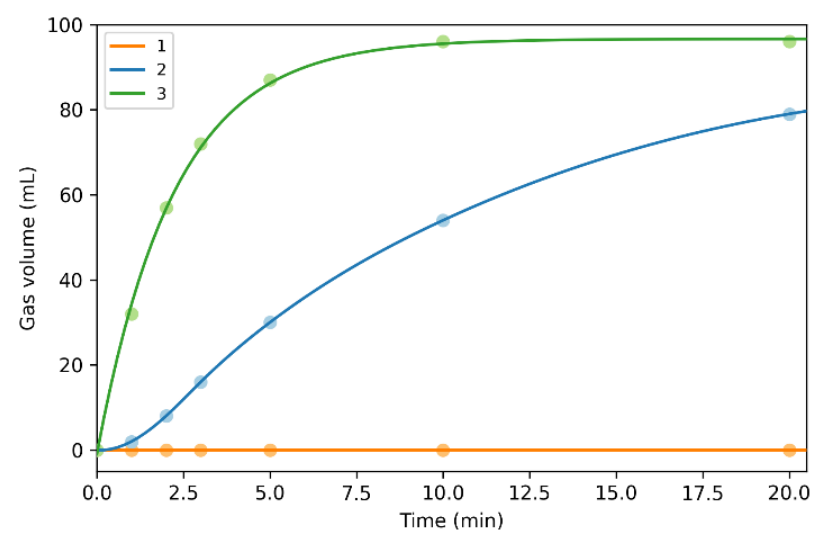

Figure 2: Kinetic profile dehydrogenation of FA catalyzed by complexes 1, 2 and 3. Reaction conditions: FA ( $2 \mathrm{mmol})$ in 1,4-dioxane $(2 \mathrm{~mL})$ and catalyst $(0.5 \mathrm{~mol} \%)$ at $80^{\circ} \mathrm{C}$. Gas evolution was measured with a graduated cylinder (see ESI for details).

To get a deeper insight into the mechanism, the reaction was computed, and the most favoured pathway is depicted in Scheme 2. Cobalt complex A, an isomer of $\mathbf{3}$ (see ESI), deprotonates an incoming molecule of FA and releases $\mathrm{H}_{2}$ through $\mathbf{T S}_{\mathbf{A B}}$, to yield the intermediate formate complex $\mathbf{B}$ ( $\mathbf{T S}_{\mathbf{A B}}: 11.9$ kcal.mol $\left.{ }^{-1}, \Delta \mathrm{G}=-4.7 \mathrm{kcal}^{\mathrm{mol}} \mathrm{m}^{-1}\right)$. The decarboxylation of $\mathbf{B}$ to regenerate $\mathbf{A}$, after release of $\mathrm{CO}_{2}$, involves in contrast several steps. While a direct $\beta$-H elimination can be considered (TS $\mathbf{S B D}_{\mathbf{B D}}$, $16.3 \mathrm{kcal}^{\mathrm{mol}}{ }^{-1}$ ), formate complex $\mathbf{B}$ was found to readily insert a second molecule of FA in the Co-OCHO bond, via TS $_{\mathbf{B C}}(1.0$ kcal.mol ${ }^{-1}$ ). The resulting complex $\mathbf{C}$ then includes a formato ligand, which is coordinated to the $\mathrm{Co}^{\mathrm{I}}$ ion via its $\mathrm{C}-\mathrm{H}$ bond and stabilized through $\mathrm{H}$-bonding with the $\mathrm{N}-\mathrm{H}$ moiety of the phosphoramine ligand and a FA molecule. $\mathbf{C}$ is $2.3 \mathrm{kcal}^{\mathrm{mol}} \mathrm{mol}^{-1}$ higher in energy than $\mathbf{A}$. After release of FA, intermediate $\mathbf{D}$ is formed, which features an H-bound formate complex, H-bonded to the participative ligand. A complex similar to $\mathbf{D}$ has also been described by Hazari, Schneider et al. ${ }^{26}$ The subsequent decarboxylation of the formato ligand in $\mathbf{D}$ occurs through $\mathbf{T S}_{\mathbf{D A}}$ (18.7 kcal.mol ${ }^{-1}, \Delta \Delta \mathrm{G}_{\mathrm{DA}}=-19.2 \mathrm{kcal} \mathrm{mol}^{-1}$ ) and closes the catalytic cycle, while the overall dehydrogenation reaction is exergonic $\left(\Delta \mathrm{G}=9.5 \mathrm{kcal} . \mathrm{mol}^{-1}\right)$. The total energetic span of the reaction, $23.4 \mathrm{kcal} . \mathrm{mol}^{-1}$, is defined by the resting state $\mathbf{B}$ and the decarboxylation step (TS $\mathbf{T S A}_{\mathbf{D A}}$ ), which is the rate-determining step. This value is consistent with our observations of a fast reaction at 80 ${ }^{\circ} \mathrm{C}$. Moreover, the non-trivial influence of the concentration in FA on the reaction rate can be rationalized with the necessity to involve two molecules of FA in the process, the first one being involved in the dehydrogenation and the second one in the decarboxylation. Interestingly, in this mechanism, the participative ligand is never deprotonated, and only acts as hydrogen bond donor.

Finally, in order to push the reaction towards a maximum TON while keeping high TOF throughout the reaction by a control of the amount of FA, a reloading experiment was set up using 3 in 1,4-dioxane (Figure 3). We observed the deactivation of the catalyst through a simultaneous decrease in TON and TOF upon each refill $\left(\mathrm{TOF}_{1 \min }\right.$ were 4000,3000 and $750 \mathrm{~h}^{-1}$ at each FA loading). It was however possible to reach a total TON of 458 over the course of a 4 hour reaction.

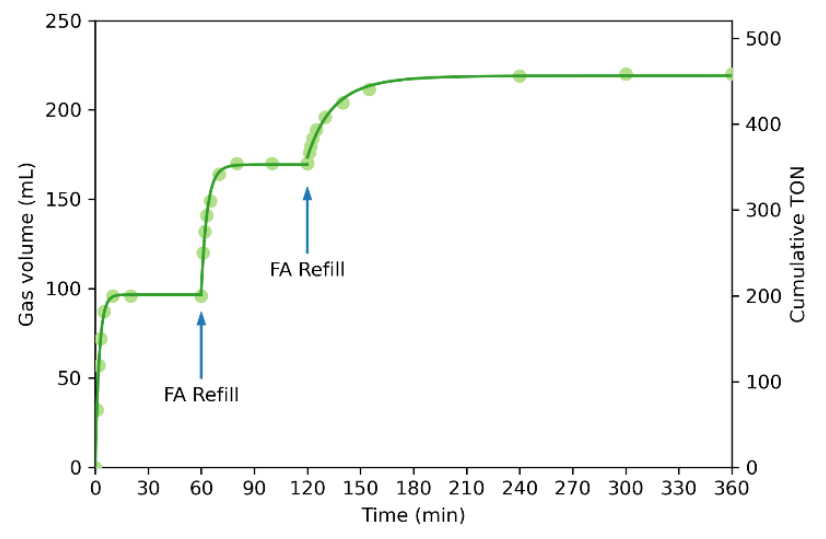

Figure 3: Kinetic profile for the dehydrogenation of FA catalysed by 3 . Reaction conditions: FA ( $2 \mathrm{mmol})$ in 1,4-dioxane $(2 \mathrm{~mL})$ and $3(0.5 \mathrm{~mol} \%)$ at $80{ }^{\circ} \mathrm{C}$. The reaction was refilled twice with FA (2 $\mathrm{mmol})$.

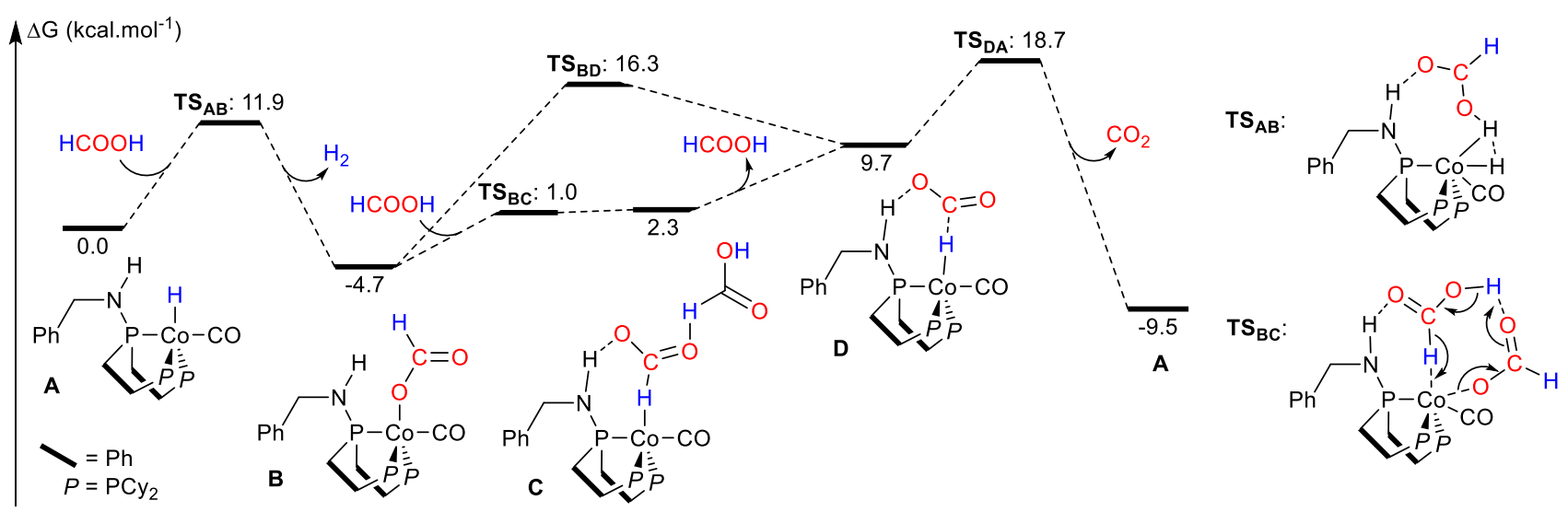

Scheme 2: Computed reaction profile for the Co-1 catalyzed formic acid dehydrogenation reaction. Computations parameters: Gaussian 16 Rev C.01; $\omega$-B97X-D/Def2-TZVP (Co), 6-311+G(d,p) (mobile H) 6-31G(d) (other atoms), SMD (Solvent: 1,4-dioxane). 
In conclusion, we described herein the synthesis of new cobalt(II) and cobalt(I) complexes, supported by a chelating participative ligand possessing a phosphoramine arm. The activity of the complexes was tested in the dehydrogenation of FA. The cobalt(I) hydrido carbonyl complex 3 was found highly reactive, pushing further the activity of homogeneous $3 \mathrm{~d}$ metal, by reaching TOF values of $4000 \mathrm{~h}^{-1}$ and a TON $\mathrm{N}_{\max }$ of 458 . It is, to the best of our knowledge, the first report of a cobalt catalyst active in the dehydrogenation of FA without addition of bases or additives. DFT calculations helped rationalizing the importance of the participative ligand and the concentration of FA, in accordance with the experimental results.

\section{ASSOCIATED CONTENT}

\section{Supporting Information}

The Supporting Information is available free of charge on the ACS Publications website.

Synthesis, characterizations, crystal structure refinements and computational investigations (PDF).

\section{ACCESSION CODES}

$\$$ CCDC numbers: 2011895 and 2011896 contain the supplementary crystallographic data for this paper. These data can be obtained free of charge from The Cambridge Crystallographic Data Centre via www.ccdc.cam.ac.uk/data_request/cif

\section{AUTHOR INFORMATION}

\section{Corresponding Author}

* Thibault Cantat - Université Paris-Saclay, CEA, CNRS, NIMBE, 91191, Gif-sur-Yvette, France. E-mail: thibault.cantat@cea.fr.

\section{Author}

Nicolas Lentz - Université Paris-Saclay, CEA, CNRS, NIMBE, 91191, Gif-sur-Yvette, France.

Alicia Aloisi - Université Paris-Saclay, CEA, CNRS, NIMBE, 91191, Gif-sur-Yvette, France.

Pierre Thuéry - Université Paris-Saclay, CEA, CNRS, NIMBE, 91191, Gif-sur-Yvette, France.

Emmanuel Nicolas - Université Paris-Saclay, CEA, CNRS, NIMBE, 91191, Gif-sur-Yvette, France.

\section{Notes}

The authors declare no competing financial interest.

\section{ACKNOWLEDGMENT}

The authors acknowledge for financial support of this work: CEA, CNRS, CINES (project sis6494), the CHARMMMAT Laboratory of Excellence, the European Research Council (ERC Consolidator Grant Agreement no. 818260), ADEME (fellowship to AA). This research was supported by the European Union's Horizon $2020 \mathrm{Re}$ search and Innovation Programme under grant agreement no. 768919, Carbon4PUR project.

\section{REFERENCES}

1. Energy, transport and environment statistics; Eurostat2019.

2. Kerskes, H., Chapter 17 - Thermochemical Energy Storage. In Storing Energy, Letcher, T. M., Ed. Elsevier: Oxford, 2016; pp 345372 .

3. Züttel, A.; Borgschulte, A.; Schlapbach, L., Hydrogen as a Future Energy Carrier. Wiley-VCH2008.
4. $\quad$ Züttel, A.; Hirscher, M.; Panella, B.; Yvon, K.; Orimo, S.-i.; Bogdanović, B.; Felderhoff, M.; Schüth, F.; Borgschulte, A.; Goetze, S.; Suda, S.; Kelly, M. T., Hydrogen Storage. In Hydrogen as a Future Energy Carrier,2008; pp 165-263.

5. $\quad$ Sordakis, K.; Tang, C.; Vogt, L. K.; Junge, H.; Dyson, P. J.; Beller, M.; Laurenczy, G., Homogeneous Catalysis for Sustainable Hydrogen Storage in Formic Acid and Alcohols. Chem. Rev. 2018, $118,372-433$.

6. $\quad$ Li, Z.; Xu, Q., Metal-Nanoparticle-Catalyzed Hydrogen Generation from Formic Acid. Acc. Chem. Res. 2017, 50, 1449-1458.

7. Onishi, N.; Laurenczy, G.; Beller, M.; Himeda, Y., Recent progress for reversible homogeneous catalytic hydrogen storage in formic acid and in methanol. Coord. Chem. Rev. 2018, 373, 317-332.

8. Mellmann, D.; Sponholz, P.; Junge, H.; Beller, M., Formic acid as a hydrogen storage material - development of homogeneous catalysts for selective hydrogen release. Chem. Soc. Rev. 2016, 45, 3954-3988.

9. $\quad$ Lu, S.-M.; Wang, Z.; Wang, J.; Li, J.; Li, C., Hydrogen generation from formic acid decomposition on a highly efficient iridium catalyst bearing a diaminoglyoxime ligand. Green Chem. 2018, 20, 1835-1840.

10. Papp, G.; Ölveti, G.; Horváth, H.; Kathó, Á.; Joó, F., Highly efficient dehydrogenation of formic acid in aqueous solution catalysed by an easily available water-soluble iridium(iii) dihydride. Dalton Trans. 2016, 45, 14516-14519.

11. Celaje, J. J. A.; Lu, Z.; Kedzie, E. A.; Terrile, N. J.; Lo, J. N.; Williams, T. J., A prolific catalyst for dehydrogenation of neat formic acid. Nature Comm. 2016, 7, 11308.

12. Wang, Z.; Lu, S.-M.; Wu, J.; Li, C.; Xiao, J., IodidePromoted Dehydrogenation of Formic Acid on a Rhodium Complex. Eur. J. Inorg. Chem. 2016, 2016, 490-496.

13. Fink, C.; Laurenczy, G., $\mathrm{CO}_{2}$ as a hydrogen vector transition metal diamine catalysts for selective $\mathrm{HCOOH}$ dehydrogenation. Dalton Trans. 2017, 46, 1670-1676.

14. Fink, C.; Laurenczy, G., A Precious Catalyst: RhodiumCatalyzed Formic Acid Dehydrogenation in Water. Eur. J. Inorg. Chem. 2019, 2019, 2381-2387.

15. Neary, M. C.; Parkin, G., Dehydrogenation, disproportionation and transfer hydrogenation reactions of formic acid catalyzed by molybdenum hydride compounds. Chem. Sci. 2015, 6, $1859-1865$.

16. Czaun, M.; Goeppert, A.; Kothandaraman, J.; May, R. B.; Haiges, R.; Prakash, G. K. S.; Olah, G. A., Formic Acid As a Hydrogen Storage Medium: Ruthenium-Catalyzed Generation of Hydrogen from Formic Acid in Emulsions. ACS Catal. 2014, 4, 311-320.

17. Pan, Y.; Pan, C.-L.; Zhang, Y.; Li, H.; Min, S.; Guo, X.; Zheng, B.; Chen, H.; Anders, A.; Lai, Z.; Zheng, J.; Huang, K.-W., Selective Hydrogen Generation from Formic Acid with Well-Defined Complexes of Ruthenium and Phosphorus-Nitrogen PN3-Pincer Ligand. Chem. Asian. J. 2016, 11, 1357-1360.

18. Mellone, I.; Bertini, F.; Peruzzini, M.; Gonsalvi, L., An active, stable and recyclable $\mathrm{Ru}(\mathrm{ii})$ tetraphosphine-based catalytic system for hydrogen production by selective formic acid dehydrogenation. Catal. Sci. Tech. 2016, 6, 6504-6512.

19. Anderson, N. H.; Boncella, J. M.; Tondreau, A. M., Reactivity of Silanes with (tBuPONOP)Ruthenium Dichloride: Facile Synthesis of Chloro-Silyl Ruthenium Compounds and Formic Acid Decomposition. Chem. Eur. J. 2017, 23, 13617-13622.

20. Esteruelas, M. A.; García-Yebra, C.; Martín, J.; Oñate, E., Dehydrogenation of Formic Acid Promoted by a Trihydride-HydroxoOsmium(IV) Complex: Kinetics and Mechanism. ACS Catal. 2018, 8, 11314-11323.

21. Guan, C.; Pan, Y.; Zhang, T.; Ajitha, M. J.; Huang, K.-W., An Update on Formic Acid Dehydrogenation by Homogeneous Catalysis. Chem. Asian. J. 2020, 15, 937-946.

22. Boddien, A.; Gärtner, F.; Jackstell, R.; Junge, H.; Spannenberg, A.; Baumann, W.; Ludwig, R.; Beller, M., orthoMetalation of Iron(0) Tribenzylphosphine Complexes: Homogeneous 
Catalysts for the Generation of Hydrogen from Formic Acid. Angew. Chem. Int. Ed. 2010, 49, 8993-8996.

23. Boddien, A.; Loges, B.; Gärtner, F.; Torborg, C.; Fumino, K.; Junge, H.; Ludwig, R.; Beller, M., Iron-Catalyzed Hydrogen Production from Formic Acid. J. Am. Chem. Soc. 2010, 132, 89248934.

24. Boddien, A.; Mellmann, D.; Gärtner, F.; Jackstell, R.; Junge, H.; Dyson, P. J.; Laurenczy, G.; Ludwig, R.; Beller, M., Efficient Dehydrogenation of Formic Acid Using an Iron Catalyst. Science 2011, 333, 1733.

25. Zell, T.; Butschke, B.; Ben-David, Y.; Milstein, D., Efficient Hydrogen Liberation from Formic Acid Catalyzed by a Well-Defined Iron Pincer Complex under Mild Conditions. Chem. Eur. J. 2013, 19, 8068-8072.

26. Bielinski, E. A.; Lagaditis, P. O.; Zhang, Y.; Mercado, B. Q.; Würtele, C.; Bernskoetter, W. H.; Hazari, N.; Schneider, S., Lewis Acid-Assisted Formic Acid Dehydrogenation Using a PincerSupported Iron Catalyst. J. Am. Chem. Soc. 2014, 136, 10234-10237. 27. Zell, T.; Milstein, D., Hydrogenation and Dehydrogenation Iron Pincer Catalysts Capable of Metal-Ligand Cooperation by Aromatization/Dearomatization. Acc. Chem. Res. 2015, 48, 19791994.

28. Mellone, I.; Gorgas, N.; Bertini, F.; Peruzzini, M.; Kirchner, K.; Gonsalvi, L., Selective Formic Acid Dehydrogenation Catalyzed by Fe-PNP Pincer Complexes Based on the 2,6-Diaminopyridine Scaffold. Organometallics 2016, 35, 3344-3349.

29. Curley, J. B.; Bernskoetter, W. H.; Hazari, N., Additive-Free Formic Acid Dehydrogenation Using a Pincer-Supported Iron Catalyst. ChemCatChem 2020, 12, 1934-1938.

30. Bertini, F.; Mellone, I.; Ienco, A.; Peruzzini, M.; Gonsalvi, L., Iron(II) Complexes of the Linear rac-Tetraphos-1 Ligand as Efficient Homogeneous Catalysts for Sodium Bicarbonate Hydrogenation and Formic Acid Dehydrogenation. ACS Catal. 2015, $5,1254-1265$.

31. Montandon-Clerc, M.; Dalebrook, A. F.; Laurenczy, G., Quantitative aqueous phase formic acid dehydrogenation using iron(II) based catalysts. J. Catal. 2016, 343, 62-67.

32. Tondreau, A. M.; Boncella, J. M., 1,2-Addition of Formic or Oxalic Acid to $-\mathrm{N}\{\mathrm{CH} 2 \mathrm{CH} 2(\mathrm{PiPr} 2)\} 2$-Supported $\mathrm{Mn}(\mathrm{I})$ Dicarbonyl Complexes and the Manganese-Mediated Decomposition of Formic Acid. Organometallics 2016, 35, 2049-2052.

33. Anderson, N. H.; Boncella, J.; Tondreau, A. M., ManganeseMediated Formic Acid Dehydrogenation. Chem. Eur. J. 2019, 25, $10557-10560$

34. Léval, A.; Agapova, A.; Steinlechner, C.; Alberico, E.; Junge, H.; Beller, M., Hydrogen production from formic acid catalyzed by a phosphine free manganese complex: investigation and mechanistic insights. Green Chem. 2020, 22, 913-920.

35. Enthaler, S.; Brück, A.; Kammer, A.; Junge, H.; Irran, E.; Gülak, S., Exploring the Reactivity of Nickel Pincer Complexes in the Decomposition of Formic Acid to $\mathrm{CO}_{2} / \mathrm{H}_{2}$ and the Hydrogenation of $\mathrm{NaHCO}_{3}$ to HCOONa. ChemCatChem 2015, 7, 65-69.

36. Neary, M. C.; Parkin, G., Nickel-catalyzed release of $\mathrm{H}_{2}$ from formic acid and a new method for the synthesis of zerovalent $\mathrm{Ni}\left(\mathrm{PMe}_{3}\right)_{4}$. Dalton Trans. 2016, 45, 14645-14650.

37. Correa, A.; Cascella, M.; Scotti, N.; Zaccheria, F.; Ravasio, N.; Psaro, R., Mechanistic insights into formic acid dehydrogenation promoted by $\mathrm{Cu}$-amino based systems. Inorg. Chim. Acta 2018, 470, 290-294.

38. Onishi, M., Decomposition of formic acid catalyzed by hydrido (phosphonite) cobalt (I) under photoirradiation. J. Mol. Catal. 1993, 80, 145-149.

39. Zhou, W.; Wei, Z.; Spannenberg, A.; Jiao, H.; Junge, K.; Junge, H.; Beller, M., Cobalt-Catalyzed Aqueous Dehydrogenation of Formic Acid. Chem. Eur. J. 2019, 25, 8459-8464.

40. Myers, T. W.; Berben, L. A., Aluminium-ligand cooperation promotes selective dehydrogenation of formic acid to $\mathrm{H}_{2}$ and $\mathrm{CO}_{2}$. Chem. Sci. 2014, 5, 2771-2777.
41. Chauvier, C.; Tlili, A.; Das Neves Gomes, C.; Thuéry, P.; Cantat, T., Metal-free dehydrogenation of formic acid to $\mathrm{H}_{2}$ and $\mathrm{CO}_{2}$ using boron-based catalysts. Chem. Sci. 2015, 6, 2938-2942.

42. Khusnutdinova, J. R.; Milstein, D., Metal-Ligand Cooperation. Angew. Chem. Int. Ed. 2015, 54, 12236-12273.

43. Zhao, B.; Han, Z.; Ding, K., The N $\square$ H Functional Group in Organometallic Catalysis. Angew. Chem. Int. Ed. 2013, 52, 47444788.

44. Agapova, A.; Alberico, E.; Kammer, A.; Junge, H.; Beller, M., Catalytic Dehydrogenation of Formic Acid with Ruthenium-PNPPincer Complexes: Comparing N-Methylated and NH-Ligands. ChemCatChem 2019, 11, 1910-1914.

45. Alig, L.; Fritz, M.; Schneider, S., First-Row Transition Metal (De)Hydrogenation Catalysis Based On Functional Pincer Ligands. Chem. Rev. 2019, 119, 2681-2751.

46. Aloisi, A.; Crochet, E.; Nicolas, E.; Berthet, J.-C.; Lescot, C.; Thuéry, P.; Cantat, T., Copper-Ligand Cooperativity in $\mathrm{H}_{2}$ Activation Enables the Synthesis of Copper Hydride Complexes. Under Revision 2020.

47. Crans, D. C.; Chen, H.; Anderson, O. P.; Miller, M. M., Vanadium(V)-protein model studies: solid-state and solution structure. J. Am. Chem. Soc. 1993, 115, 6769-6776.

48. Whitfield, J. M.; Watkins, S. F.; Tupper, G. B.; Baddley, W. H., Preparation and crystal structure of transcarbonylhydridotris(triphenylphosphine)cobalt(I): a quantitative assessment of trigonal bipyramidal geometry. J. Chem. Soc., Dalton Trans. 1977, 407-413.

49. Lagaditis, P. O.; Schluschaß, B.; Demeshko, S.; Würtele, C.; Schneider, S., Square-Planar Cobalt(III) Pincer Complex. Inorg. Chem. 2016, 55, 4529-4536.

50. $\quad$ Fu, S.; Chen, N.-Y.; Liu, X.; Shao, Z.; Luo, S.-P.; Liu, Q., Ligand-Controlled Cobalt-Catalyzed Transfer Hydrogenation of Alkynes: Stereodivergent Synthesis of Z- and E-Alkenes. J. Am. Chem. Soc. 2016, 138, 8588-8594.

51. Heimann, J. E.; Bernskoetter, W. H.; Hazari, N.; Mayer, James M., Acceleration of $\mathrm{CO}_{2}$ insertion into metal hydrides: ligand, Lewis acid, and solvent effects on reaction kinetics. Chem. Sci. 2018, 9, 6629-6638.

52. Heimann, J. E.; Bernskoetter, W. H.; Hazari, N., Understanding the Individual and Combined Effects of Solvent and Lewis Acid on $\mathrm{CO}_{2}$ Insertion into a Metal Hydride. J. Am. Chem. Soc. 2019, 141, 10520-10529. 


\title{
Additive-Free Formic Acid Dehydrogenation Catalyzed by a Cobalt Complex
}

\author{
Nicolas Lentz, Alicia Aloisi, Pierre Thuéry, Emmanuel Nicolas and Thibault \\ Cantat* \\ Université Paris-Saclay, CEA, CNRS, NIMBE, 91191, Gif-sur-Yvette, France. E-mail: \\ thibault.cantat@cea.fr
}

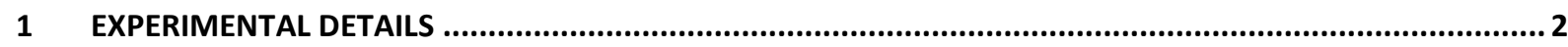

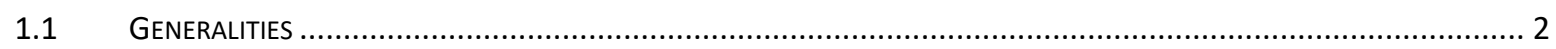



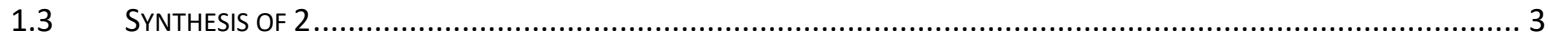

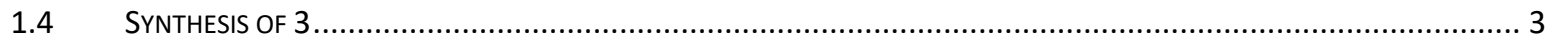

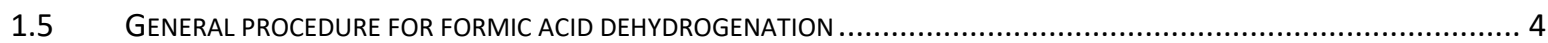

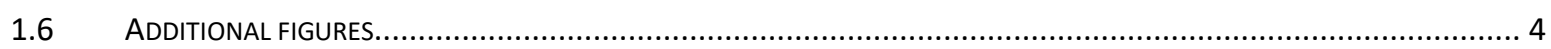

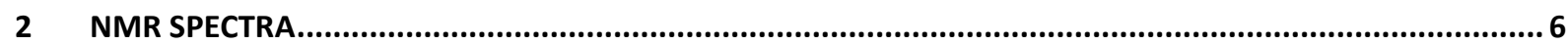

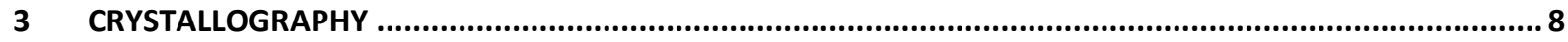

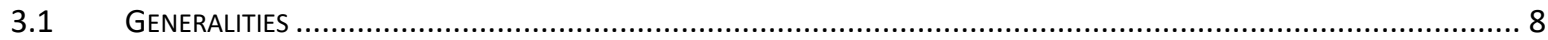

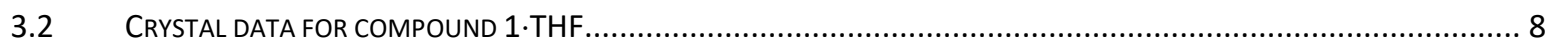

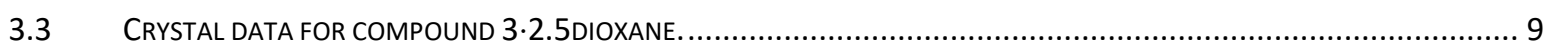

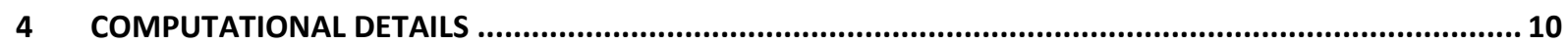

4.1 FULL REACTION SCHEME, INCLUDING 3 (E) TO A ISOMERISATION AND DIRECT B-H ELIMINATION FROM B .................. 10

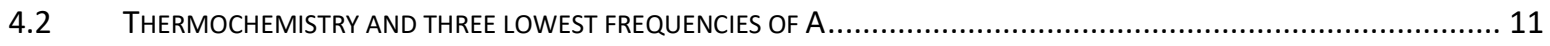

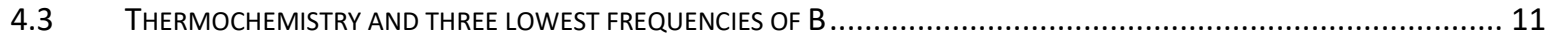

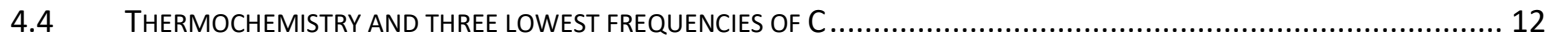

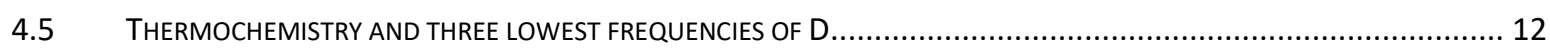

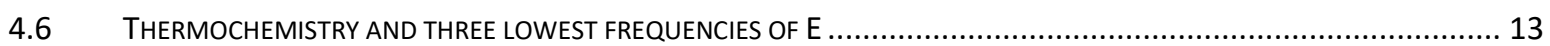

4.7 THERMOCHEMISTRY AND THREE LOWEST FREQUENCIES OF TS

4.8 THERMOCHEMISTRY AND THREE LOWEST FREQUENCIES OF TS

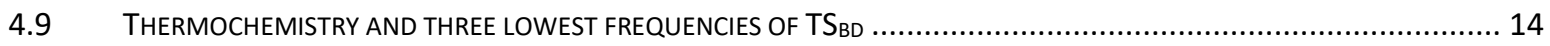

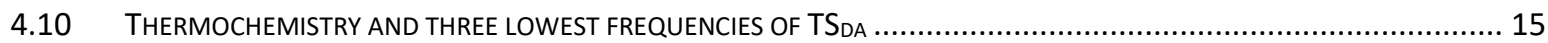

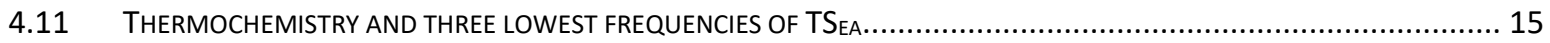

4.12 THERMOCHEMISTRY AND THREE LOWEST FREQUENCIES OF H H

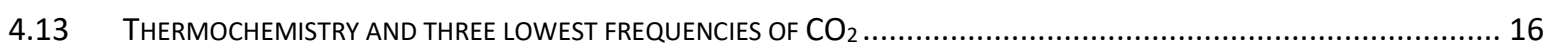

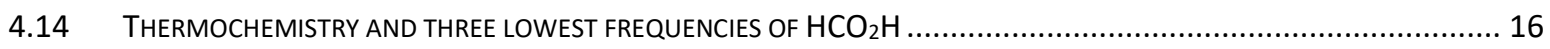

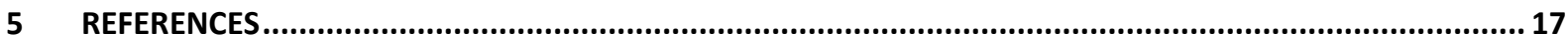




\section{Experimental Details}

\subsection{Generalities}

All reactions were performed under an inert atmosphere of argon using standard Schlenk line and glovebox techniques and dry deoxygenated solvents. Tetrahydrofuran (THF), $d^{8}$-tetrahydrofuran $\left(d^{8}-\right.$ THF), toluene, pentane and $\mathrm{d}^{6}$-benzene were dried over a $\mathrm{Na} /$ benzophenone mixture, vacuum-distilled before use and if necessary, stored over activated $4 \AA$ molecular sieves. $\mathrm{CD}_{3} \mathrm{CN}$ and $\mathrm{CD}_{2} \mathrm{Cl}_{2}$ were dried over $\mathrm{CaH}_{2}$ and vacuum-distilled before use. Unless stated otherwise, all other reagents and chemicals were obtained commercially and used as received.

Mass spectra were measured with direct chemical ionization ( $\left.\mathrm{DCl}-\mathrm{CH}_{4}\right)$ methods, and recorded on a GCT Premier Waters mass spectrometer. MEDAC Ltd. performed the elemental analyses.

$\mathrm{PP}(\mathrm{NH}) \mathrm{P}$ was prepared according to a literature procedure. ${ }^{1}$

Nuclear magnetic resonance spectra were recorded on a Bruker Avance Neo spectrometer operating at $400.18 \mathrm{MHz}$ for ${ }^{1} \mathrm{H}$. Solvent peaks were used as an internal reference relative to $\mathrm{Me}_{4} \mathrm{Si}$ for ${ }^{1} \mathrm{H}$ and ${ }^{13} \mathrm{C}$ chemical shifts (ppm); ${ }^{31} \mathrm{P}$ chemical shifts are externally referenced to $85 \% \mathrm{H}_{3} \mathrm{PO}_{4}$. Coupling constants are given in Hertz. The following abbreviations are used: $s$, singlet; $d$, doublet; $t$, triplet; $m$, multiplet.

Effective magnetic moments are measured with the Evans method, using $2 \%$ Acetone in THF-d8 as a reference.

\subsection{Synthesis of 1}<smiles>ClC(Cl)(P(Cl)(Cl)(Cl)Cl)P(Cl)(Cl)(c1ccccc1)c1ccccc1P(Cl)(Cl)(Cl)Cl</smiles>

PP(NH)P (79 mg, $0.115 \mathrm{mmol}, 1 \mathrm{eq})$ was dissolved in THF (15 mL) and added slowly to $\mathrm{Co}(\mathrm{Cl})_{2}(15 \mathrm{mg}, 0.115 \mathrm{mmol}, 1 \mathrm{eq})$. The reaction mixture was then stirred for $2 \mathrm{~h}$ at $80^{\circ} \mathrm{C}$. The mixture was finally cooled to room temperature and the volatiles were evaporated. The resulting solid was finally washed with pentane $(3 \times 3 \mathrm{~mL})$ in order to give a brown powder quantitatively. XRD quality crystals of $\mathbf{1}$ were obtained from a saturated solution in THF.

E.A. Calc: C, 63.47; H, 7.43; N, 1.72. Observed: C, 63.76; H, 7.36; N, 1.44.

$\mu_{\text {eff }}=2.49 \mu_{\mathrm{B}}$ 


\subsection{Synthesis of 2}<smiles>COC1(OC)P(Cl)(Cl)(Cl)c2ccccc2P12(NCc1ccccc1)c1ccccc1P2(=O)OC</smiles>

PP(NH)P (158 mg, $0.23 \mathrm{mmol}, 1 \mathrm{eq})$ was dissolved in THF (25 mL) and added slowly to $\mathrm{Co}(\mathrm{OAc})_{2}(41 \mathrm{mg}, 0.23 \mathrm{mmol}, 1 \mathrm{eq})$. The reaction mixture was then stirred for $2 \mathrm{~h}$ at $80{ }^{\circ} \mathrm{C}$. The mixture was finally cooled to room temperature and the volatiles were evaporated. The resulting solid was finally washed with pentane $(3 \times 5 \mathrm{~mL})$ in order to give a brown powder quantitatively.

E.A. Calc: C, 63.57; H, 7.73; N, 1.63. Observed: C, 63.11; H, 7.75; N, 1.39.

$\mu_{\text {eff }}=3.18 \mu_{\mathrm{B}}$

\subsection{Synthesis of 3}

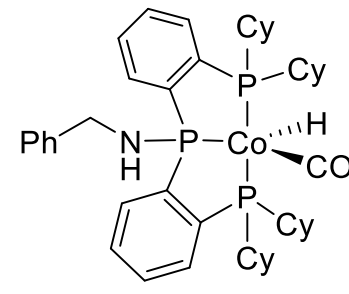

1 or 2 (0.23 mmol, 1eq) were dissolved in THF (25 mL) and $\mathrm{Me}_{3} \mathrm{SiOCHO}(82$ $\mathrm{mg}, 0.69 \mathrm{mmol}, 3 \mathrm{eq})$ was added slowly to the mixture. After heating $16 \mathrm{~h}$ at $80^{\circ} \mathrm{C}$, the mixture was cooled to room temperature and volatiles were evaporated. The resulting solid was finally washed with pentane $(3 \times 5 \mathrm{~mL})$ in order to give an orange powder in a $86 \%$ yield (153 mg, $0.20 \mathrm{mmol}$ ). Crystals of 3 were obtained from a saturated solution in 1,4-dioxane.

${ }^{1} \mathrm{H}$ NMR $\left(300.18 \mathrm{MHz}, \mathrm{C}_{6} \mathrm{D}_{6}, 25^{\circ} \mathrm{C}\right): \delta-10.91\left(\mathrm{dt},{ }^{2} \mathrm{~J}_{\mathrm{HP}}=78.2 \mathrm{~Hz},{ }^{2} \mathrm{~J}_{\mathrm{HP}}=50.6 \mathrm{~Hz}, 1 \mathrm{H}, \mathrm{Co}-\boldsymbol{H}\right) ; 1.06-1.42(\mathrm{~m}$, $16 \mathrm{H}, \mathrm{Cy}) ; 1.56-1.83(\mathrm{~m}, 22 \mathrm{H}, \mathrm{Cy}) ; 1.90(\mathrm{t}, \mathrm{J}=7.0 \mathrm{~Hz}, 1 \mathrm{H}, \mathrm{NH}) ; 2.26(\mathrm{~m}, 2 \mathrm{H}, \mathrm{Cy}) ; 2.34(\mathrm{~m}, 2 \mathrm{H}, \mathrm{Cy}) ; 2.37$ $(\mathrm{m}, 2 \mathrm{H}, \mathrm{Cy}) ; 4.08\left(\mathrm{t}, \mathrm{J}=6.5 \mathrm{~Hz}, 2 \mathrm{H}, \mathrm{NH}-\mathrm{CH}_{2}-\mathrm{Ph}\right) ; 7.04-7.17\left(\mathrm{~m}, 7 \mathrm{H}, \mathrm{CH}_{A r}\right) ; 7.35\left(\mathrm{~d}, \mathrm{~J}=7.2 \mathrm{~Hz}, 2 \mathrm{H}, \mathrm{C} \boldsymbol{H}_{A r}\right)$; $7.46\left(\mathrm{~d}, \mathrm{~J}=7.1 \mathrm{~Hz}, 2 \mathrm{H}, \mathrm{C} \boldsymbol{H}_{A r}\right) ; 8.00\left(\mathrm{t}, \mathrm{J}=6.4 \mathrm{~Hz}, 2 \mathrm{H}, \mathrm{CH}_{A r}\right)$.

${ }^{13} \mathrm{C}\left\{{ }^{1} \mathrm{H}\right\}$ NMR $\left(75.48 \mathrm{MHz}, \mathrm{C}_{6} \mathrm{D}_{6}, 25^{\circ} \mathrm{C}\right): \delta 26.8(C y) ; 27.4(C y) ; 27.5(C y) ; 27.6(C y) ; 27.7(C y) ; 27.9(C y) ;$ $28.0(C y) ; 29.2$ (Cy); $29.3(C y) ; 29.6(C y) ; 38.6$ (t, J = $13.9 \mathrm{~Hz}, C y) ; 39.7$ (t, J = 13.9 Hz, Cy); 48.4 (d, J = 7.3 Hz, NH-CH $2-P h) ; 127.2\left(\boldsymbol{C}_{\mathrm{Ar}}\right) ; 127.9\left(\boldsymbol{C}_{\mathrm{Ar}}\right) ; 128.2\left(\boldsymbol{C}_{\mathrm{Ar}}\right) ; 128.6\left(\boldsymbol{C}_{\mathrm{Ar}}\right) ; 128.7\left(\mathrm{~d}, \mathrm{~J}=8.2 \mathrm{~Hz}, \boldsymbol{C}_{\mathrm{Ar}}\right) ; 129.1$ $\left(\boldsymbol{C}_{\mathrm{Ar}}\right) ; 129.3\left(\mathrm{dd}, \mathrm{J}=11.3 \mathrm{~Hz}, \mathrm{~J}=4.5 \mathrm{~Hz}, \boldsymbol{C}_{\mathrm{Ar}}\right) ; 141.8\left(\mathrm{~d}, \mathrm{~J}=11.4 \mathrm{~Hz}, \boldsymbol{C}_{\mathrm{Ar} / \mathrm{q}}\right) ; 147.3(\mathrm{dt}, \mathrm{J}=50.8 \mathrm{~Hz}, \mathrm{~J}=11.0$ $\left.\mathrm{Hz}, \boldsymbol{C}_{\mathrm{Ar} / \mathrm{q}}\right) ; 151.1\left(\mathrm{dt}, \mathrm{J}=44.9 \mathrm{~Hz}, \mathrm{~J}=24.0 \mathrm{~Hz}, \boldsymbol{C}_{\mathrm{Ar} / \mathrm{q}}\right)$.

${ }^{31} \mathrm{P}\left\{{ }^{1} \mathrm{H}\right\} \mathrm{NMR}\left(162 \mathrm{MHz}, \mathrm{C}_{6} \mathrm{D}_{6}, 25^{\circ} \mathrm{C}\right): \delta 95.5,157.8 \mathrm{ppm}$.

IR $\left(\mathrm{cm}^{-1}\right): 1902$ (s) (CO).

HRMS m/z (\%): 392.180320 (M+2+ACN-CO), 371.667257 (M+2-CO-ACN) calcd for 392.180166 $\left(\mathrm{M}^{+2}+\mathrm{ACN}-\mathrm{CO}\right), 371.666892\left(\mathrm{M}^{+2}-\mathrm{CO}-\mathrm{ACN}\right)$.

E.A. Calc: C, 68.47; H, 7.97; N, 1.81. Observed: C, 64.48; H, 8.03; N, 1.53. High reactivity and degradation of the complex might explain the difference in Elemental Analysis result. 


\subsection{General procedure for formic acid dehydrogenation}

In a round bottom flask equipped with a condenser, the catalyst $(0.5 \mathrm{~mol} \%, 10 \mu \mathrm{mol})$ was dissolved in the solvent. Then, formic acid $(75 \mu \mathrm{L}, 2 \mathrm{mmol})$ was added. The mixture was stirred and heated at $80^{\circ} \mathrm{C}$ for the desired time and evolution of gas was measured with a graduated cylinder filled with water.

To account for temperature changes that can affect the measurements of evolved gas volume, a blank reaction without any catalyst was performed. The blank volume was observed to be constant within ca. $1 \mathrm{~mL}$ over the course of the reaction, and was removed to all measured gas volumes.

The turnover number (TON) was thus calculated by the following equation:

$$
\text { TON }=\frac{V_{\text {measured }}-V_{\text {blank }}}{\left(V_{m, \mathrm{H}_{2}, 25^{\circ} \mathrm{C}}+V_{m, \mathrm{CO}_{2}, 25^{\circ} \mathrm{C}}\right) * n_{\text {catalyst }}}
$$

Where $\mathrm{V}_{\text {measured }}$ and $\mathrm{V}_{\text {blank }}$ are the volume of gas measured in the catalytic reaction and blank reaction, $\mathrm{V}_{\mathrm{m}}$ are the molar volume of $\mathrm{H}_{2}$ and $\mathrm{CO}_{2}$, respectively, and $\mathrm{n}_{\text {catalyst }}$ is the molar amount of catalyst.

The turnover frequency (TOF) was calculated by the following equation:

$$
T O F=\frac{T O N}{t}
$$

Where $\mathrm{t}$ is the time in hour.

\subsection{Additional figures}

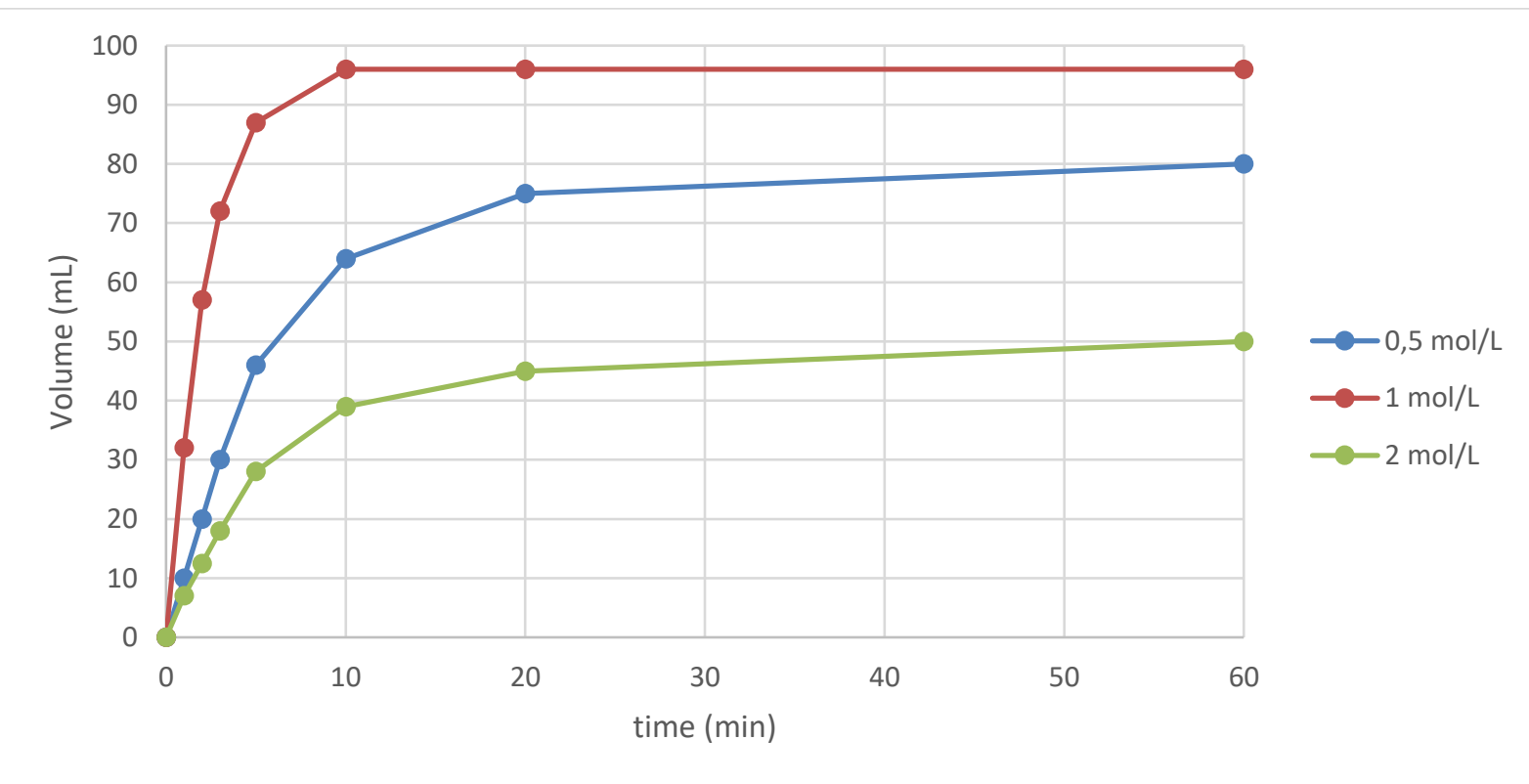

Figure 1: Dehydrogenation of formic acid catalyzed by 3 at different concentration 


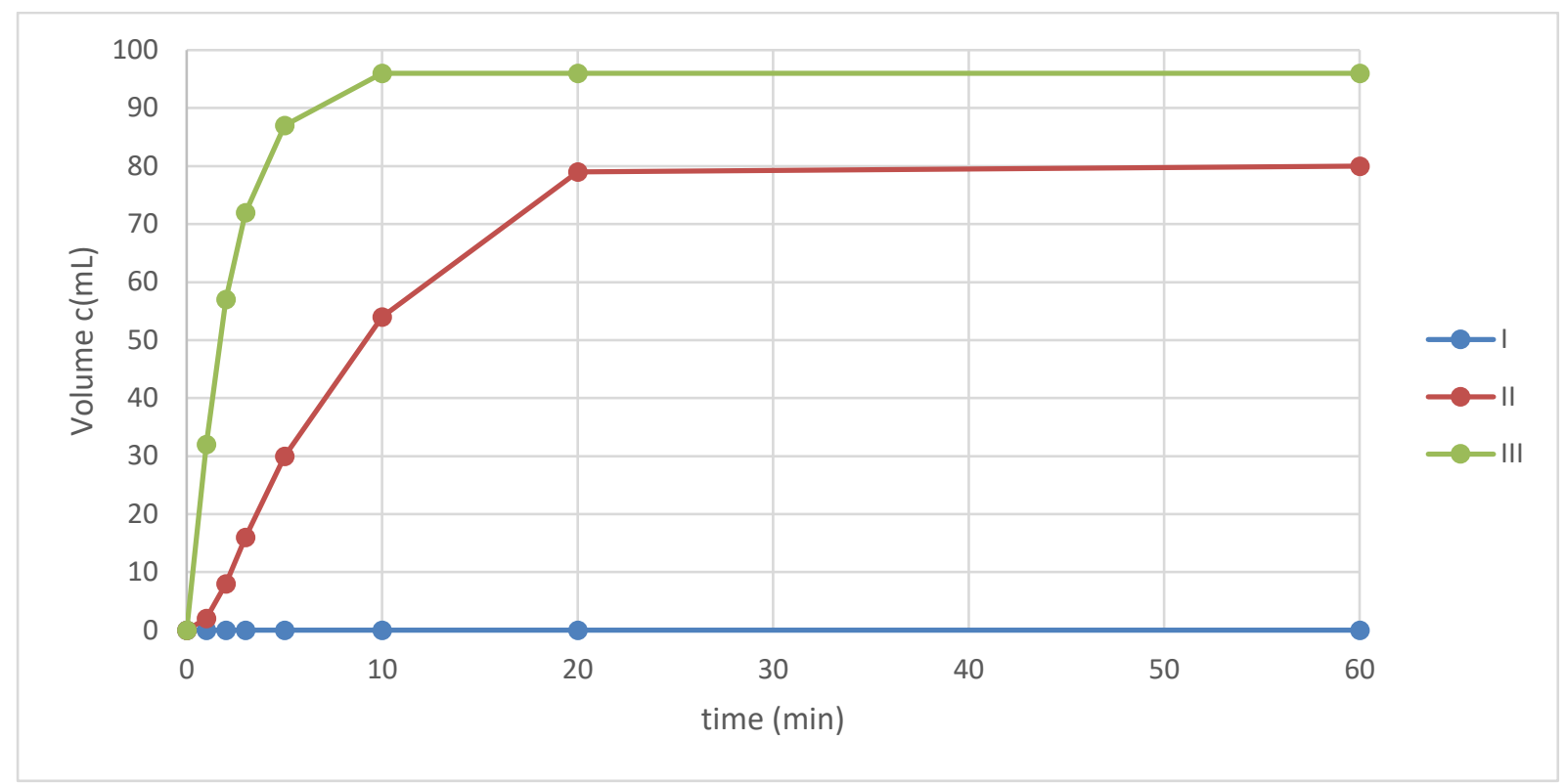

Figure 2: Dehydrogenation of formic acid catalyzed by 1, 2 or 3

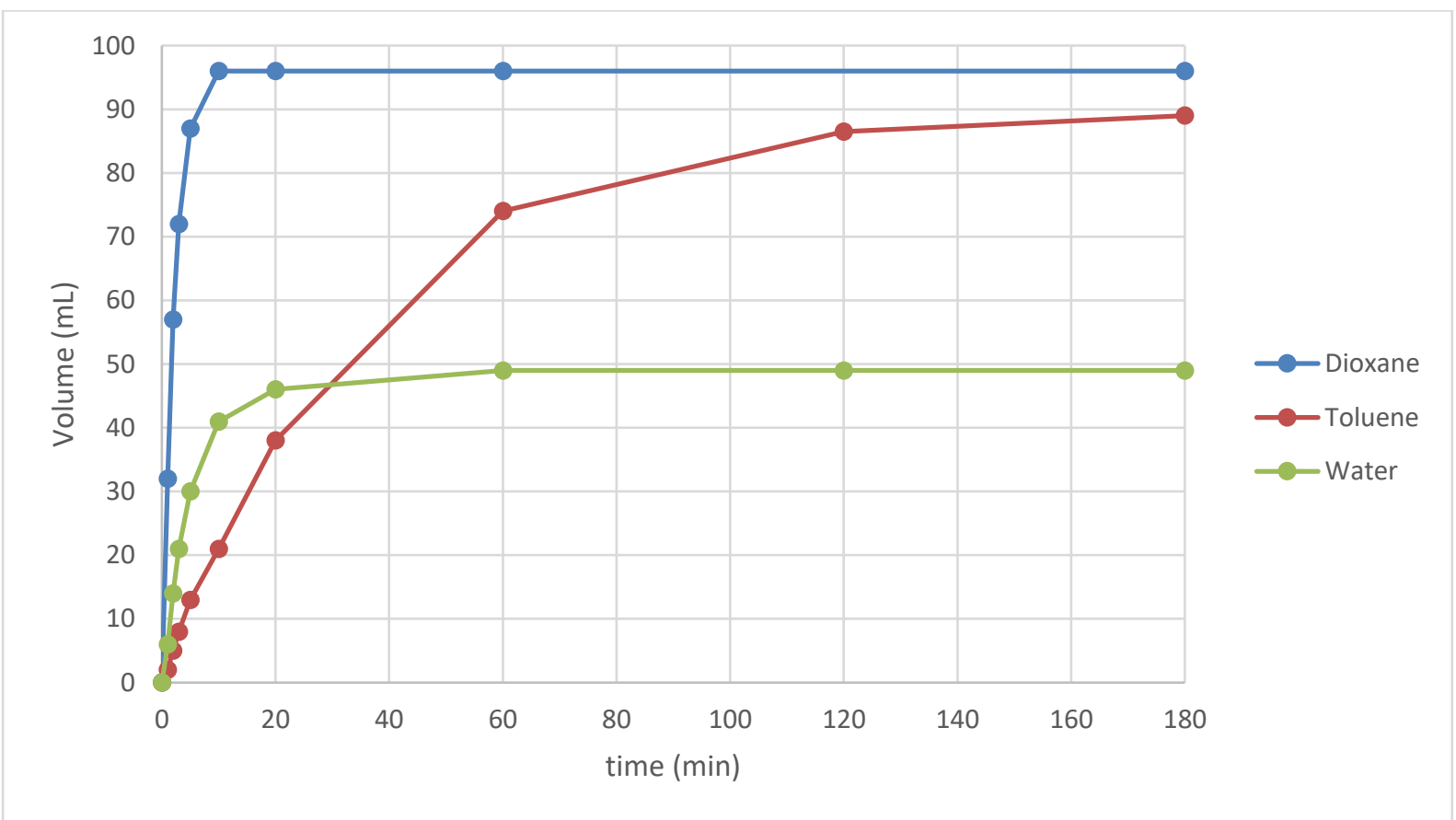

Figure 3: Dehydrogenation of formic acid catalyzed by 3 in different solvents 


\section{NMR spectra}


Figure 4: ${ }^{31} \mathrm{P}$ NMR spectrum of the reaction of 2 with $\mathrm{FA}$ at $150{ }^{\circ} \mathrm{C}(\mathrm{THF}-\mathrm{d} 8,400 \mathrm{MHz})$

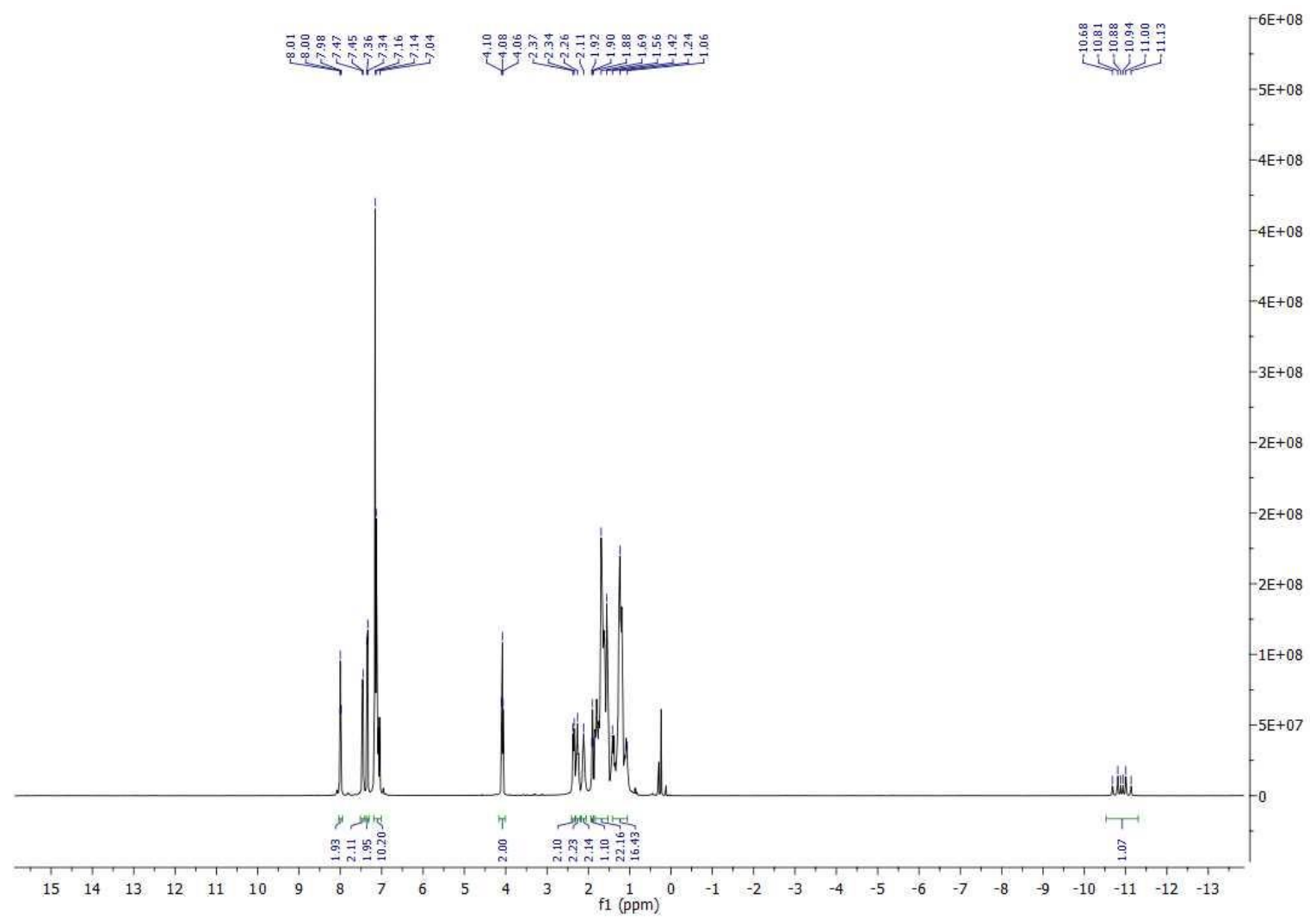

Figure 5: ${ }^{1} \mathrm{H}$ NMR spectrum of compound $3\left(\mathrm{C}_{6} \mathrm{D}_{6}, 400 \mathrm{MHz}\right)$ 


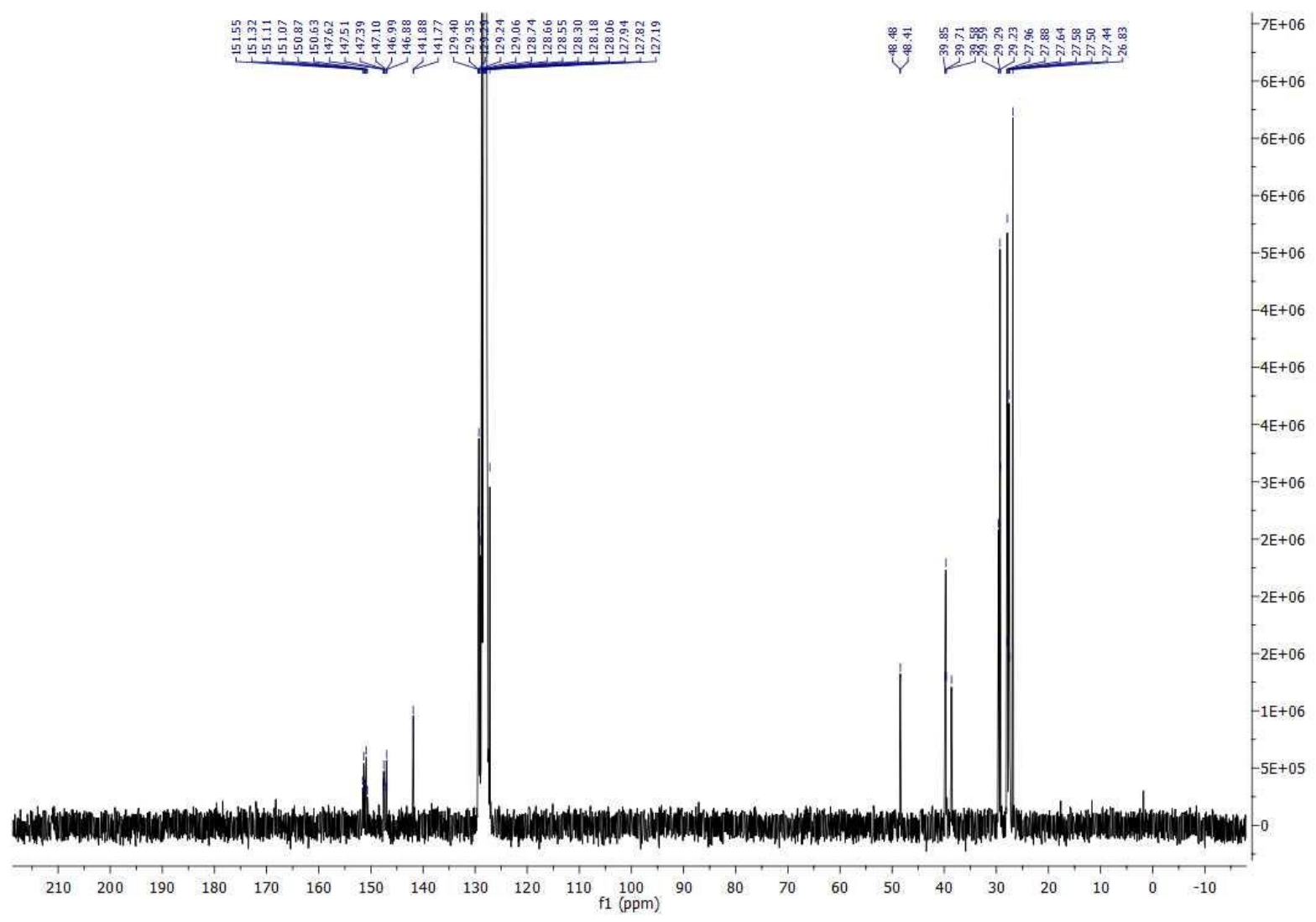

Figure $6:{ }^{13} \mathrm{C}$ NMR spectrum of compound $3\left(C_{6} D_{6}, 100 \mathrm{MHz}\right)$



Figure 7: ${ }^{31} \mathrm{P}$ NMR spectrum of compound $3\left(\mathrm{C}_{6} \mathrm{D}_{6}, 162 \mathrm{MHz}\right)$ 


\section{Crystallography}

\subsection{Generalities}

The data for compounds 1.THF and 3.2.5 dioxane were collected at 150(2) and 180(2) K, respectively, on a Nonius Kappa-CCD area detector diffractometer using graphite-monochromated Mo-K $\alpha$ radiation $(\lambda=0.71073 \AA) .^{2}$ The crystals were introduced into glass capillaries with a protective coating of Paratone-N oil (Hampton Research). The unit cell parameters were determined from ten frames, then refined on all data. The data (combination of $\phi$ - and $\omega$-scans with a minimum redundancy of 4 for $90 \%$ of the reflections) were processed with HKL2000. ${ }^{32}$ Absorption effects were corrected empirically with the program SCALEPACK. ${ }^{3}$ The structures were solved by intrinsic phasing with SHELXT, ${ }^{4}$ and refined by full-matrix least-squares on $F^{2}$ with SHELXL-2014. ${ }^{5}$ All non-hydrogen atoms were refined with anisotropic displacement parameters. The carbon-bound hydrogen atoms were introduced at calculated positions and were treated as riding atoms with an isotropic displacement parameter equal to 1.2 times that of the parent atom. The hydrogen atoms bound to N1 in 1.THF, and to CO1 and N1 in 3.2.5dioxane were found on difference Fourier maps and were fully refined. In 3.2.5dioxane, one phenyl ring is disordered over two positions which were refined as idealized hexagons with occupancy parameters constrained to sum to unity, and the carbon atoms of one dioxane molecule are also disordered over two positions refined with occupancy parameters constrained to sum to unity. The molecular plots were drawn with ORTEP-3. ${ }^{6}$

\subsection{Crystal data for compound 1.THF}

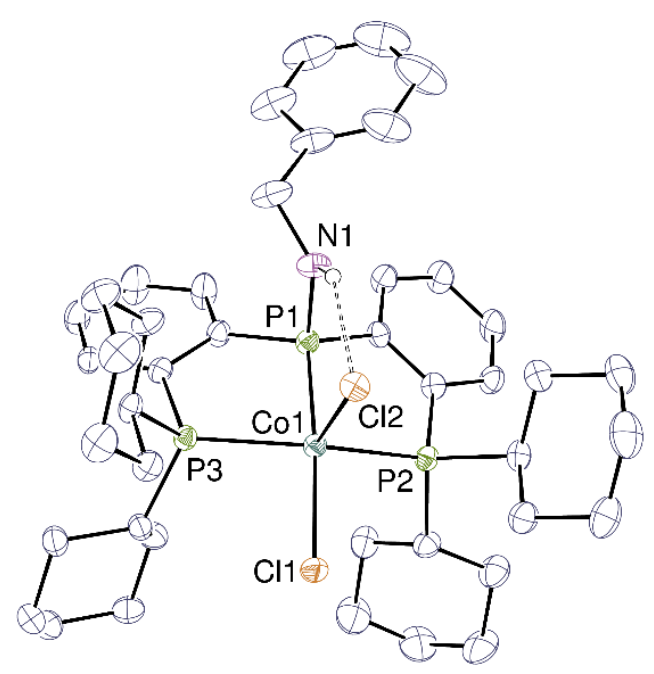

$\mathrm{C}_{47} \mathrm{H}_{68} \mathrm{Cl}_{2} \mathrm{CoNOP}_{3}, M=885.76$, tetragonal, space group $P 4_{1}, a=b=18.7647(6), c=13.3487(3) \AA, V=$ $4700.3(3) \AA^{3}, Z=4, D_{c}=1.252 \mathrm{~g} \mathrm{~cm}^{-3}, \mu=0.615 \mathrm{~mm}^{-1}, F(000)=1884$. Refinement of 501 parameters on 8915 independent reflections out of 85712 measured reflections $\left(R_{\text {int }}=0.037\right)$ led to $R_{1}=0.037, w R_{2}$ $=0.093, S=1.065, \Delta \rho_{\max }=0.47, \Delta \rho_{\min }=-0.34$ e $\AA^{-3}$, Flack parameter $=-0.015(17)$. 


\subsection{Crystal data for compound 3·2.5dioxane.}

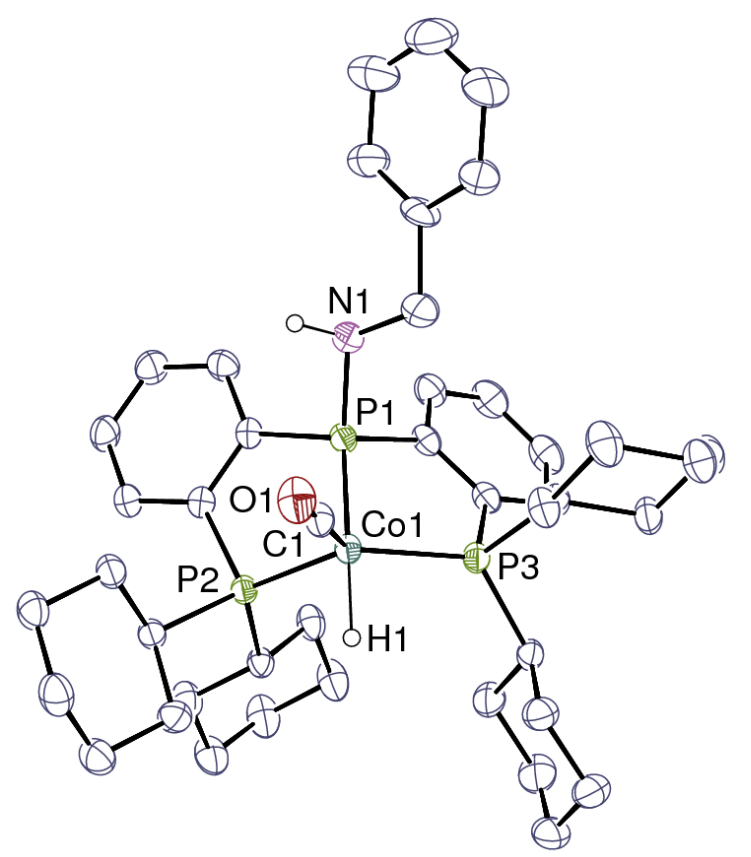

$\mathrm{C}_{54} \mathrm{H}_{81} \mathrm{CoNO}_{6} \mathrm{P}_{3}, M=992.03$, triclinic, space group $P \overline{\mathrm{I}}, a=9.7525(7), b=14.4386(8), c=19.8509(14) \AA$, $\alpha=90.861(3), \quad \beta=103.951(3), \quad \gamma=105.460(3)^{\circ}, \quad V=2605.2(3) \AA^{3}, \quad Z=2, \quad D_{c}=1.265 \mathrm{~g} \cdot \mathrm{cm}^{-3}$, $\mu=0.470 \mathrm{~mm}^{-1}, F(000)=1064$. Refinement of 662 parameters on 9861 independent reflections out of 98082 measured reflections $\left(R_{\text {int }}=0.063\right)$ led to $R_{1}=0.045, w R_{2}=0.123, S=1.040, \Delta \rho_{\max }=0.38$, $\Delta \rho_{\min }=-0.59 \mathrm{e} \cdot \AA^{-3}$. 


\section{Computational Details}

Theoretical calculations were performed with the GAUSSIAN16, Rev C.01 series of programs. ${ }^{7}$ The $\omega B 97 X D$ functional was used in combination with the 6-31G(d) basis set for all non-metal-atoms $(C, H$, $N, P), 6-311+G(d, p)$ for mobile hydrogens (e.g. involved in the reaction) and the Def2-TZVP basis set for cobalt. ${ }^{8}$ Solvent effects were taken into account using the SMD model (Solvent $=$ Dioxane) as implemented in the software. ${ }^{9}$ The stationary points were characterized as minima by full vibration frequencies calculations (no imaginary frequency).

For each molecule, energies and three lowest frequencies are reported. XYZ coordinates of all computed species can be found in the attached xyz file. Data was extracted using the Geac software. ${ }^{10}$ Pictures were realized with Cylview. ${ }^{11}$

\subsection{Full reaction scheme, including 3 (E) to $A$ isomerisation and direct $\beta-H$ elimination from $B$}

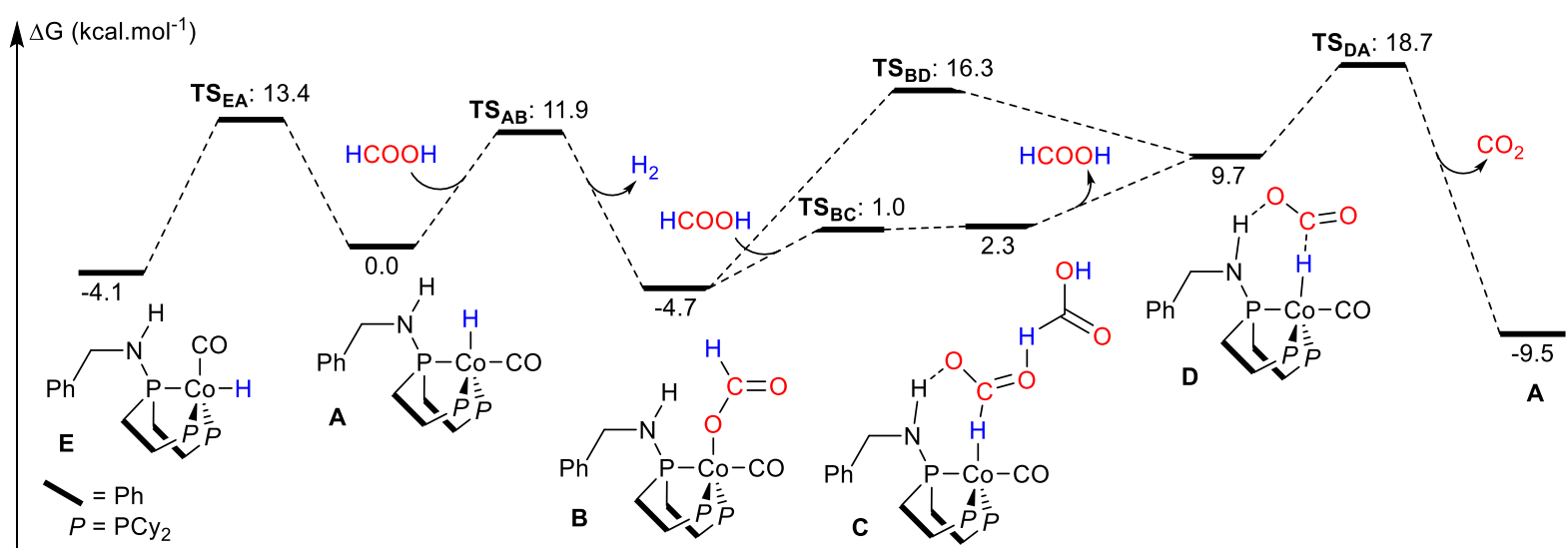




\subsection{Thermochemistry and three lowest frequencies of $A$}

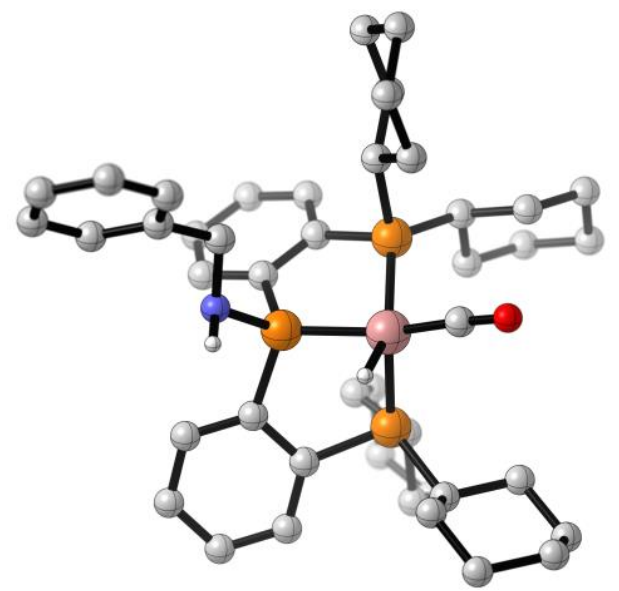

\begin{tabular}{|c|c|c|c|c|}
\hline & & 1 & 2 & \\
\hline & & A & A & \\
\hline Frequencies & -- & 13.3948 & 19.2357 & \\
\hline Red. masses & -- & 5.2860 & 3.8285 & \\
\hline Frc consts & -- & 0.0006 & 0.0008 & \\
\hline IR Inten & -- & 0.0617 & 0.1798 & \\
\hline Sum of elect & tronic & and zero-point Energies= & & -4248.862066 \\
\hline Sum of elect & tronic & and thermal Energies= & & -4248.813607 \\
\hline Sum of elect & tronic & and thermal Enthalpies= & & -4248.812663 \\
\hline Sum of elect & tronic & and thermal Free Energie & $S=$ & -4248.94497 \\
\hline
\end{tabular}

$\mathrm{HF}=-4249.84203690$

\subsection{Thermochemistry and three lowest frequencies of B}

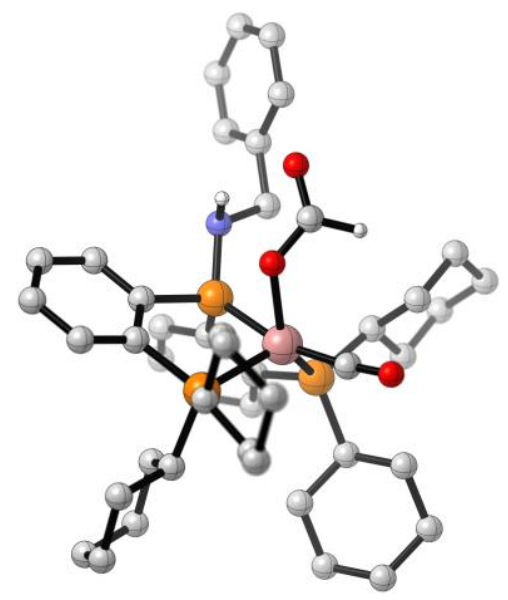

\begin{tabular}{|c|c|c|c|c|}
\hline & & 1 & 2 & \\
\hline & & A & A & \\
\hline Frequencies & -- & 17.1383 & 19.3040 & \\
\hline Red. masses & -- & 4.3765 & 4.5499 & \\
\hline Frc consts & -- & 0.0008 & 0.0010 & \\
\hline IR Inten & -- & 0.0308 & 0.2434 & \\
\hline Sum of elect & tronic & and zero-point Energies= & & -4437.378029 \\
\hline Sum of elect & tronic & and thermal Energies= & & -4437.326230 \\
\hline Sum of elect & tronic & and thermal Enthalpies= & & -4437.325286 \\
\hline Sum of elect & tronic & and thermal Free Energies & $e s=$ & -4437.464287 \\
\hline
\end{tabular}




\subsection{Thermochemistry and three lowest frequencies of C}

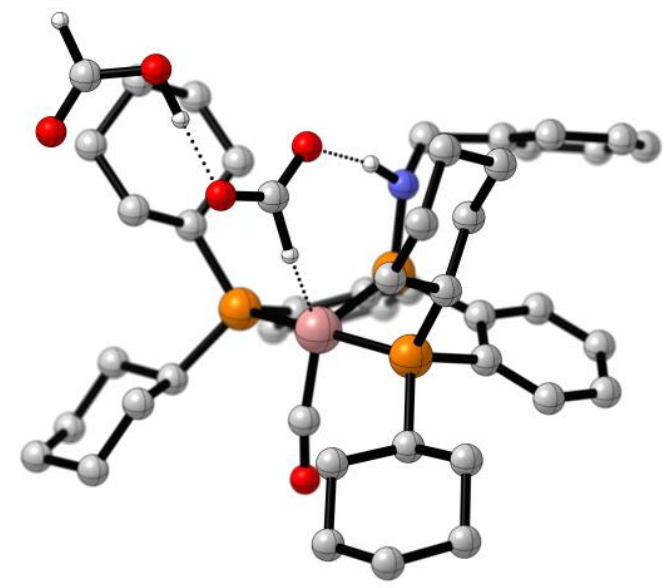

\begin{tabular}{lcrr} 
& \multicolumn{1}{c}{1} & \multicolumn{1}{c}{2} & \multicolumn{1}{c}{3} \\
& \multicolumn{1}{c}{ A } & \multicolumn{1}{c}{ A } & \multicolumn{1}{c}{ A } \\
Frequencies -- & 21.7545 & 22.8652 & 24.9499 \\
Red. masses -- & 4.5455 & 5.8757 & 6.4427 \\
Frc consts -- & 0.0013 & 0.0018 & 0.0024 \\
IR Inten -- & 0.2990 & 0.9380 & 1.0953
\end{tabular}

Sum of electronic and zero-point Energies=

Sum of electronic and thermal Energies=

$-4627.050723$

Sum of electronic and thermal Enthalpies=

$-4626.994782$

Sum of electronic and thermal Free Energies=

$-4626.993838$

$-4627.141528$

$\mathrm{HF}=-4628.08450711$

\subsection{Thermochemistry and three lowest frequencies of $D$}

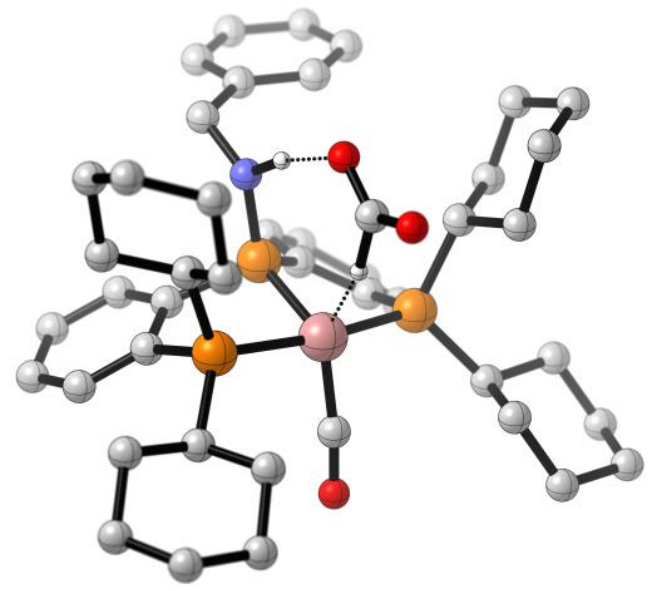

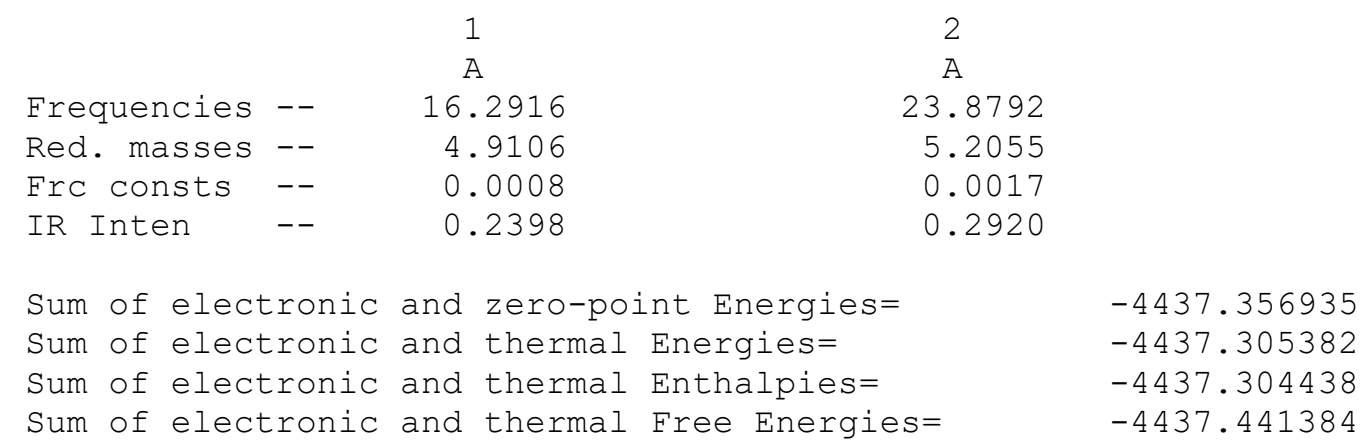

3

A

30.2342

4.4598

0.0024

0.8748 


\subsection{Thermochemistry and three lowest frequencies of $E$}

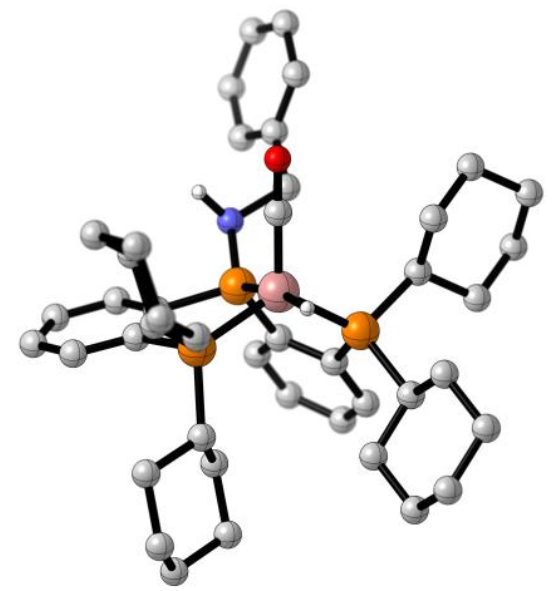

\begin{tabular}{|c|c|c|c|c|}
\hline & 1 & 2 & 3 \\
\hline & & A & A & A \\
\hline Frequencies & -- & 5.8864 & 17.8271 & 22.5877 \\
\hline Red. masses & -- & 5.2464 & 4.3859 & 3.7880 \\
\hline Frc consts & -- & 0.0001 & 0.0008 & 0.0011 \\
\hline IR Inten & -- & 0.0512 & 0.0146 & 0.1329 \\
\hline
\end{tabular}

Sum of electronic and zero-point Energies=

Sum of electronic and thermal Energies=

$-4248.868183$

$-4248.819879$

Sum of electronic and thermal Enthalpies=

$-4248.818935$

Sum of electronic and thermal Free Energies=

$-4248.951450$

$\mathrm{HF}=-4249.84905501$

\subsection{Thermochemistry and three lowest frequencies of $\mathrm{TS}_{\mathrm{AB}}$}

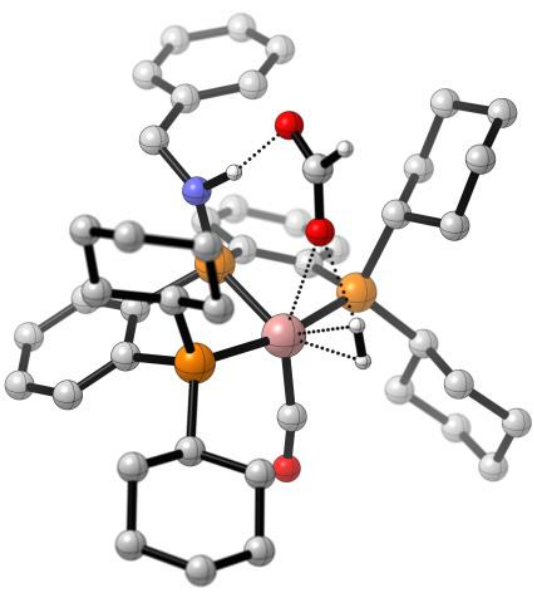



3

24.2675

4.9393

0.0017

0.1903 


\subsection{Thermochemistry and three lowest frequencies of $T S_{B C}$}

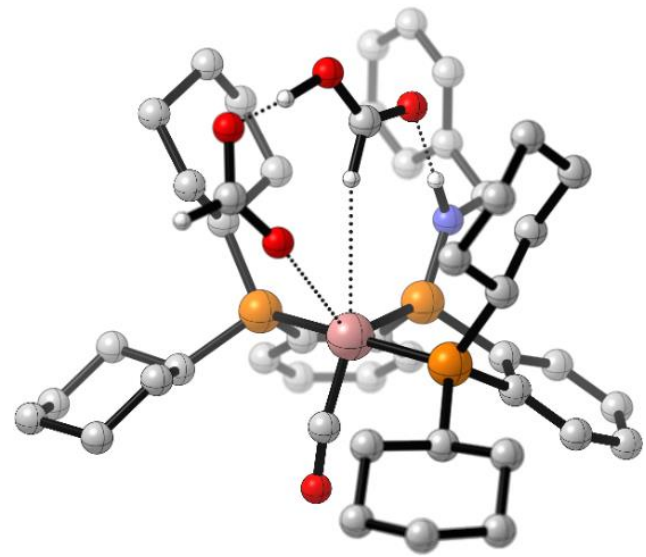

\begin{tabular}{|c|c|c|c|c|}
\hline & & 1 & 2 & 3 \\
\hline & & A & A & A \\
\hline Frequencies & -- & -26.3177 & 16.5294 & 23.1177 \\
\hline Red. masses & -- & 8.3682 & 5.1855 & 4.5722 \\
\hline Frc consts & -- & 0.0034 & 0.0008 & 0.0014 \\
\hline IR Inten & -- & 4.7829 & 0.1208 & 0.2101 \\
\hline
\end{tabular}

Sum of electronic and zero-point Energies=

Sum of electronic and thermal Energies=

$-4627.054201$

Sum of electronic and thermal Enthalpies=

$-4626.998947$

Sum of electronic and thermal Free Energies=

$-4626.998003$

$-4627.143638$

$\mathrm{HF}=-4628.08633127$

\subsection{Thermochemistry and three lowest frequencies of $\mathrm{TS}_{\mathrm{BD}}$}

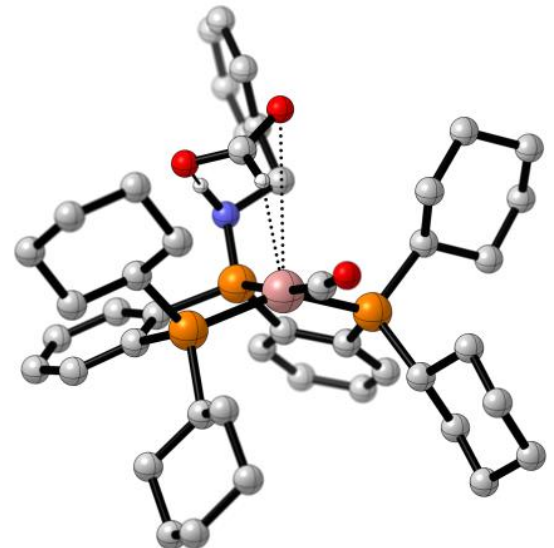

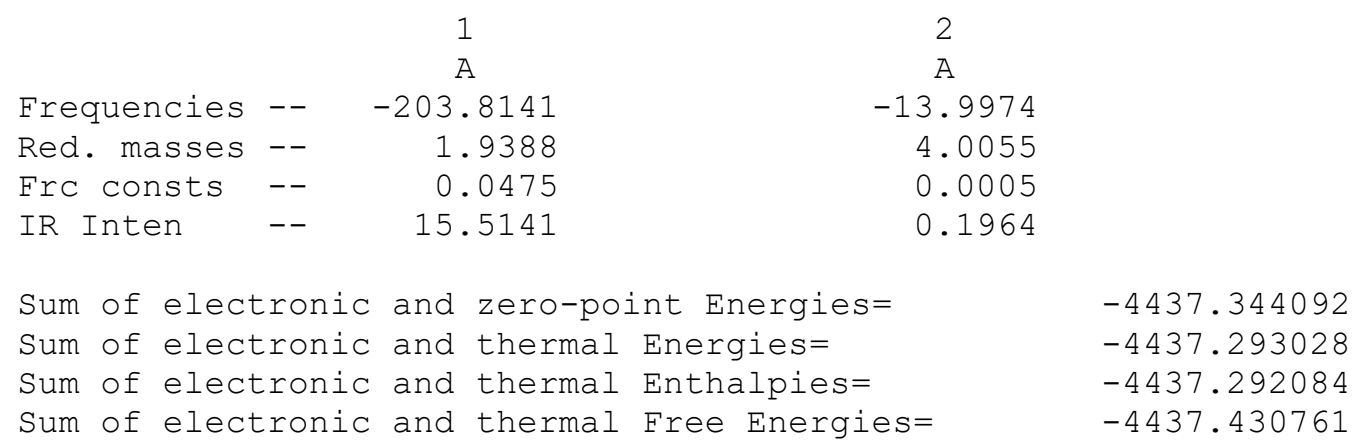

$\mathrm{HF}=-4438.34072803$

TS $_{\mathrm{BD}}$ could not be fully optimized, with only one minor imaginary frequency remaining. 


\subsection{Thermochemistry and three lowest frequencies of $T S_{D A}$}

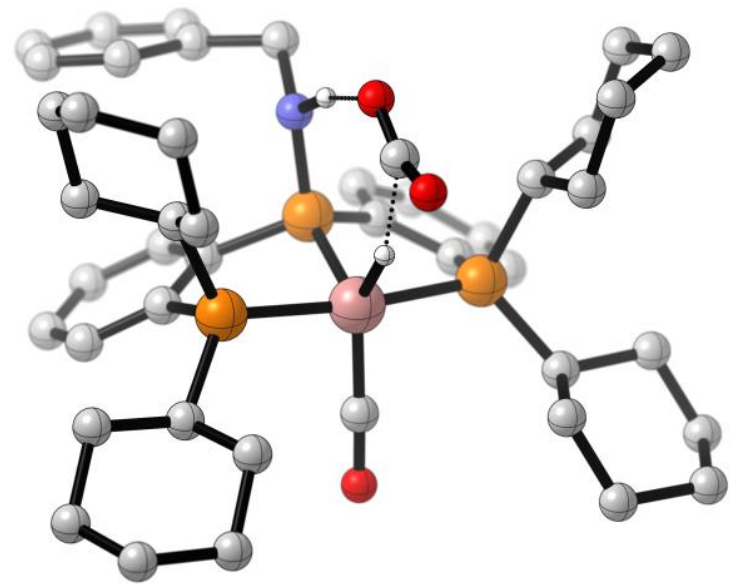

\begin{tabular}{|c|c|c|c|c|}
\hline & & 1 & 2 & \\
\hline & & A & A & \\
\hline Frequencies & -- & -486.0048 & 17.0104 & \\
\hline Red. masses & -- & 3.2436 & 5.2147 & \\
\hline Frc consts & -- & 0.4514 & 0.0009 & \\
\hline IR Inten & -- & 1582.2274 & 0.1301 & \\
\hline Sum of elect & tronic & c and zero-point Energies= & & -4437.342043 \\
\hline Sum of elect & tronic & $c$ and thermal Energies $=$ & & -4437.290442 \\
\hline Sum of elect & tronic & c and thermal Enthalpies= & & -4437.289498 \\
\hline Sum of elect & tronic & c and thermal Free Energies & $S=$ & -4437.426927 \\
\hline
\end{tabular}

$\mathrm{HF}=-4438.33390912$

\subsection{Thermochemistry and three lowest frequencies of $T S_{E A}$}

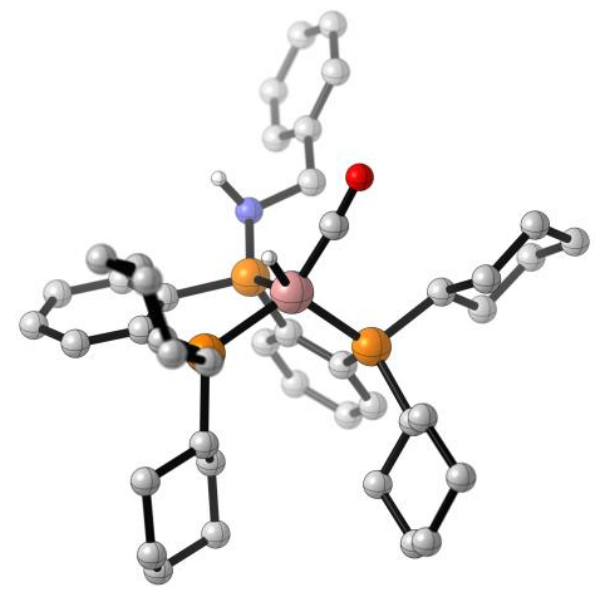

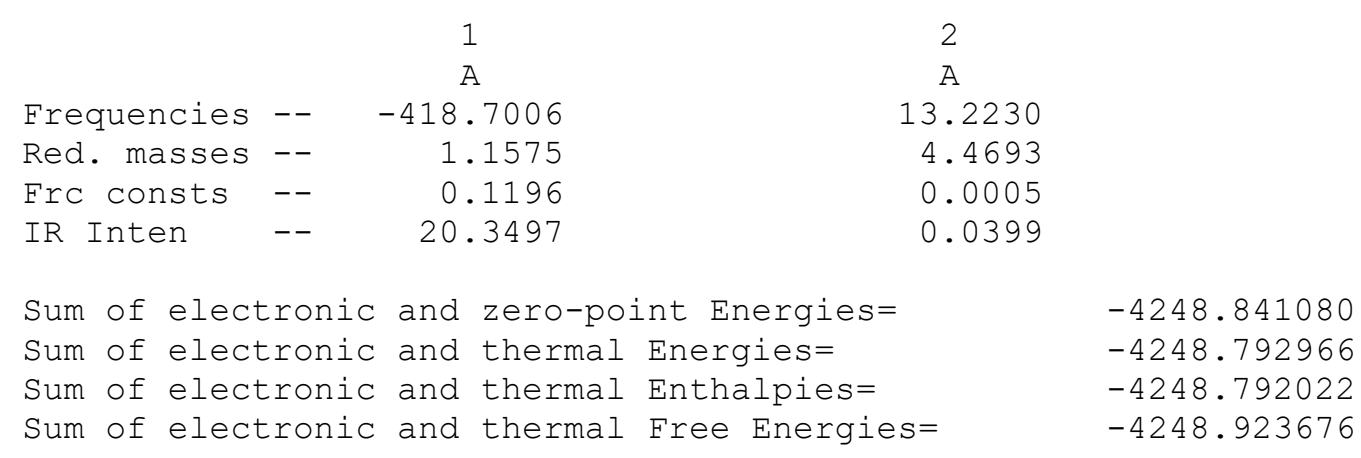




\subsection{Thermochemistry and three lowest frequencies of $\mathrm{H}_{2}$}

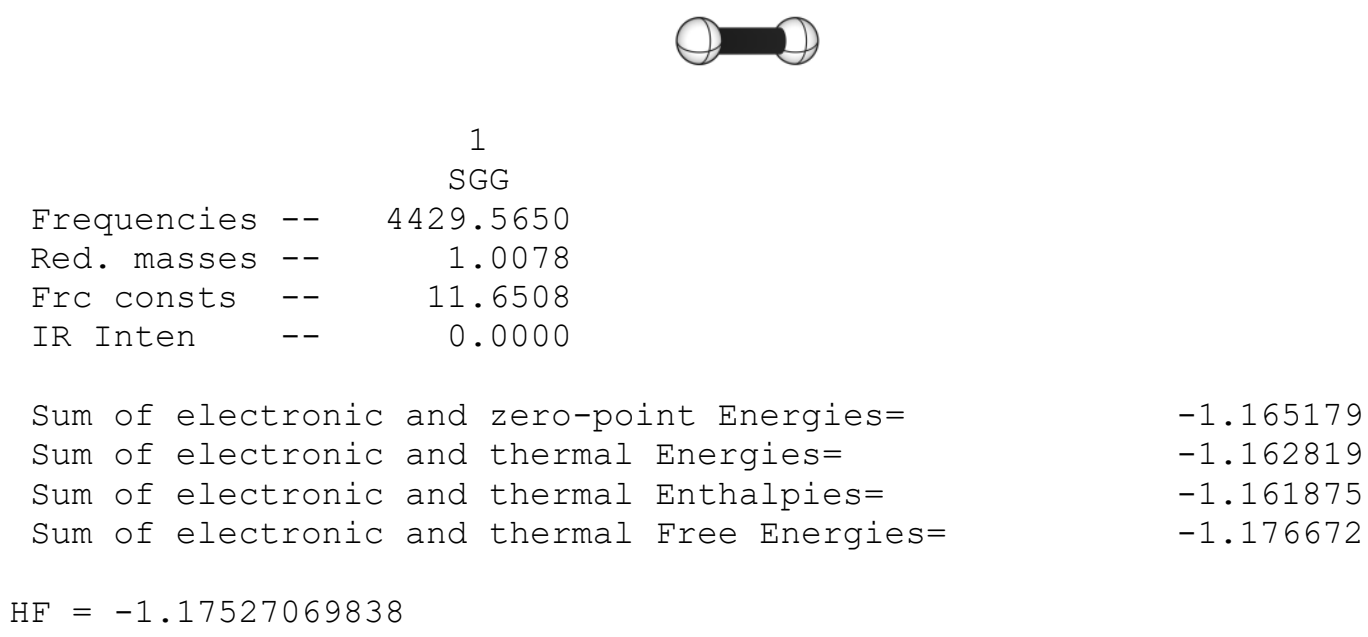

\subsection{Thermochemistry and three lowest frequencies of $\mathrm{CO}_{2}$}

\begin{tabular}{lcrr} 
& 1 & 2 & \multicolumn{1}{c}{3} \\
& PIU & PIU & SGG \\
Frequencies - & 655.8894 & 655.8894 & 1401.0925 \\
Red. masses -- & 12.8774 & 12.8774 & 15.9949 \\
Frc consts -- & 3.2639 & 3.2639 & 18.4997 \\
IR Inten -- & 39.7520 & 39.7520 & 0.0000 \\
Sum of electronic and zero-point Energies= & -188.506185 \\
Sum of electronic and thermal Energies= & -188.503554 \\
Sum of electronic and thermal Enthalpies= & -188.502610 \\
Sum of electronic and thermal Free Energies= & -188.526891 \\
HF - & &
\end{tabular}

\subsection{Thermochemistry and three lowest frequencies of $\mathrm{HCO}_{2} \mathrm{H}$}

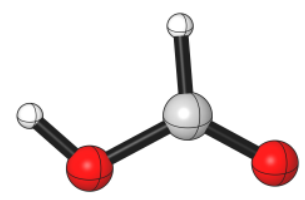

\begin{tabular}{lcrr} 
& 1 & 2 & \multicolumn{1}{c}{3} \\
& $\mathrm{~A}$ & $\mathrm{~A}$ & $\mathrm{~A}$ \\
Frequencies -- & 536.7728 & 676.8322 & 1064.6142 \\
Red. masses -- & 1.1207 & 6.3041 & 1.6812 \\
Frc consts -- & 0.1903 & 1.7015 & 1.1227 \\
IR Inten -- & 101.3425 & 11.1052 & 0.7235 \\
Sum of electronic and zero-point Energies= & -189.664382 \\
Sum of electronic and thermal Energies= & -189.661164 \\
Sum of electronic and thermal Enthalpies= & -189.660220 \\
Sum of electronic and thermal Free Energies= & -189.688450 \\
HF - & &
\end{tabular}




\section{References}

A. Aloisi, E. Crochet, E. Nicolas, J.-C. Berthet, C. Lescot, P. Thuéry and T. Cantat, Under Revision, 2020.

Collect, R. W. W. Hooft, The Netherlands, 1998,

[20] processing of $x$-ray diffraction data collected in oscillation mode, Z. Otwinowski and W. Minor, in Methods enzymol., Academic Press, 1997, vol. 276, pp. 307-326.

4 G. Sheldrick, Acta Crystallographica Section A, 2015, 71, 3-8.

$5 \quad$ G. Sheldrick, Acta Crystallographica Section C, 2015, 71, 3-8.

6 L. Farrugia, J. Appl. Crystallogr., 2012, 45, 849-854.

7 Gaussian 16 rev. C.01, M. J. Frisch, G. W. Trucks, H. B. Schlegel, G. E. Scuseria, M. A. Robb, J. R. Cheeseman, G. Scalmani, V. Barone, G. A. Petersson, H. Nakatsuji, X. Li, M. Caricato, A. V. Marenich, J. Bloino, B. G. Janesko, R. Gomperts, B. Mennucci, H. P. Hratchian, J. V. Ortiz, A. F. Izmaylov, J. L. Sonnenberg, Williams, F. Ding, F. Lipparini, F. Egidi, J. Goings, B. Peng, A. Petrone, T. Henderson, D. Ranasinghe, V. G. Zakrzewski, J. Gao, N. Rega, G. Zheng, W. Liang, M. Hada, M. Ehara, K. Toyota, R. Fukuda, J. Hasegawa, M. Ishida, T. Nakajima, Y. Honda, O. Kitao, H. Nakai, T. Vreven, K. Throssell, J. A. Montgomery Jr., J. E. Peralta, F. Ogliaro, M. J. Bearpark, J. J. Heyd, E. N. Brothers, K. N. Kudin, V. N. Staroverov, T. A. Keith, R. Kobayashi, J. Normand, K. Raghavachari, A. P. Rendell, J. C. Burant, S. S. Iyengar, J. Tomasi, M. Cossi, J. M. Millam, M. Klene, C. Adamo, R. Cammi, J. W. Ochterski, R. L. Martin, K. Morokuma, O. Farkas, J. B. Foresman and D. J. Fox, Wallingford, CT, 2016,

(a) R. Krishnan, J. S. Binkley, R. Seeger and J. A. Pople, J. Chem. Phys., 1980, 72, 650-654;

(b) W. J. Hehre, R. Ditchfield and J. A. Pople, J. Chem. Phys., 1972, 56, 2257-2261;

(c) P. C. Hariharan and J. A. Pople, Theor. Chim. Acta, 1973, 28, 213-222; (d)

M. S. Gordon, J. S. Binkley, J. A. Pople, W. J. Pietro and W. J. Hehre, J. Am. Chem. Soc., 1982, 104, 2797-2803; (e) M. M. Francl, W. J. Pietro, W. J. Hehre, J. S. Binkley, M. S. Gordon, D. J. DeFrees and J. A. Pople, J. Chem. Phys., 1982, 77, 3654-3665; (f) R. Ditchfield, W. J. Hehre and J. A. Pople, J. Chem. Phys., 1971, 54, 724-728; $\quad$ (g) F. Weigend and R. Ahlrichs, Phys. Chem. Chem. Phys., 2005, 7, 3297.

9 A. V. Marenich, C. J. Cramer and D. G. Truhlar, The Journal of Physical Chemistry B, 2009, 113, 6378-6396.

10 Geac: Gaussian esi automated creator, E. Nicolas, 2016, https://github.com/LaTruelle/Geac

11 Cylview, 1.0b, C. Y. Legault, 2009, http://www.cylview.org 